CUADERNOS DE ESTUDIOS GALLEGOS, LX Núm. 126 (enero-diciembre 2013), págs. 51-84

ISSN: $0210-847 \mathrm{X}$

DOI: 10.3989/ceg.2013.126.02

\title{
LA MIGRACIÓN DE LOS CÉLTICOS Y TÚRDULOS DE LA BETURIA HACIA EL NOROESTE DE HISPANIA
}

\author{
Juan Carlos Olivares Pedreño \\ Universidad de Alicante
}




\title{
LA MIGRACIÓN DE LOS CÉLTICOS Y TÚRDULOS DE LA BETURIA HACIA EL NOROESTE DE HISPANIA
}

RESUMEN

El presente trabajo parte del texto de Estrabón en el que afirma que los célticos de Gallaecia procedían de las orillas del Guadiana, desde donde se desplazaron junto a los túrdulos. Formulamos la hipótesis de que esa migración se produjo en el contexto de las guerras lusitanas, en concreto, desde el proconsulado de Fabius Maximus Seruilianus en el año 141 a.C. A esta conclusión se llega a partir de datos que se desprenden del texto de Estrabón; del contexto político-militar existente en ese momento en el área de la Beturia céltica, cuando se producen las campañas militares más destructivas por parte de los ejércitos romanos; de huellas de abandono de asentamientos en núcleos poblados betúricos en esa época y, finalmente, por cambios en el poblamiento de diversas áreas del noroeste hispano a mediados del s. II a.C. En este esquema adquiere más coherencia esa migración como inicio de la leyenda del río Limia como "río del Olvido", que estuvo muy presente entre las tropas de Junius Brutus durante el 137 a.C., cuando llevaron a cabo su expedición hasta el río Miño.

Palabras clave: Gallaecia, célticos, túrdulos, Beturia, migraciones.

\section{A MIGRACIÓN DOS CÉLTICOS E TÚRDULOS DA BETURIA CARA AO NOROESTE DE HISPANIA}

RESUMO

O presente traballo parte do texto de Estrabón no que afirma que os célticos de Gallaecia procedían das beiras do Guadiana, dende onde se desprazaron xunto aos túrdulos. Formulamos a hipótese de que esa migración se produciu no contexto das guerras lusitanas, en concreto, dende o proconsulado de Fabius Maximus Seruilianus durante o ano 141 a.C. A esta conclusión chégase a partir de datos que se desprenden do texto de Estrabón; do contexto político-militar existente nese momento na área da Beturia céltica, en que se producen as campañas militares máis destrutivas por parte dos exércitos romanos; de rastros de abandono de asentamentos en núcleos poboados betúricos nesa época e, finalmente, por cambios no poboamento de diversas áreas do noroeste hispano a mediados do s. II a.C. Neste contexto adquire máis coherencia esa migración como inicio da lenda do río Limia como "río do Esquecemento", que estivo moi presente entre as tropas de Junius Brutus durante o 137 a.C., cando levaron a cabo a súa expedición ata o río Miño.

PAlabras Clave: Gallaecia, célticos, túrdulos, Beturia, migracións.

\section{THE MIGRATION OF CELTS AND TURDULIANS FROM THE BETURIA TOWARDS THE NORTHWEST OF HISPANIA}

\begin{abstract}
The present work departs from a text of Strabo in which the author affirms that the celtic peoples of Gallaecia came from the banks of the river Guadiana, from where they moved together with the turdulians. We formulate the hypothesis that this migration took place in the context of the Lusitanian wars, concretely during the Fabius Maximus Seruilianus proconsulship (141 B.C.). This theory is based on Strabo's information; on the political and military context in that period in the area of Beturia, where the most destructive military campaigns by the Roman armies were taking place; on the fact that many populated places in Beturia were abandoned in this time and, finally, for changes in the population of diverse areas of the Hispanic northwest in the middle of the second century B.C. In this context, the migration of the celts and turdulians acquires more coherence as beginning of the legend of the river Limia as "Oblivion river", for it influenced Junius Brutus's troops during 137 B.C., when they carried out the expedition up to the river Miño.
\end{abstract}

KEY WORDS: Gallaecia, celts, turdulians, Beturia, migrations. 
Recibido/Received: 31/05/2013

Aceptado/Accepted: 19/08/2013

$\mathrm{E}$ estudio de los procesos migratorios en la Antigüedad ha sido tradicionalmente eludido por la gran cantidad de dificultades que plantea ${ }^{1}$. Es conocido que cuando las comunidades se mueven, desaparecen durante ese tiempo muchos rastros de su cultura material y, además, los registros escritos sobre su historia y su vida en sociedad dejan de ser conservados. En ocasiones, las informaciones sobre estas migraciones son ofrecidas a posteriori por las propias comunidades que viajan, a partir del momento en que vuelven a ubicarse en un espacio concreto, o por otras sociedades estables que se ven afectadas por aquellas durante su desplazamiento. En cualquier caso, se echa de menos una metodología específica para el análisis de estos procesos históricos que permita solucionar, en parte, la infravaloración de sus consecuencias históricas y su invisibilidad arqueológica².

El presente estudio tiene su origen en un texto de Estrabón que hace referencia a los pueblos célticos que habitaban el noroeste de Hispania, y a los túrdulos, que habitaban la costa atlántica al sur del río Duero. El geógrafo, haciendo referencia a los pueblos que habitaban la costa hispana del Océano, decía lo siguiente:

Los que viven más alejados son los ártabros, en las proximidades del cabo que llaman Nerio, que separa los flancos occidental y norte. En sus cercanías viven celtas, emparentados con los de las orillas del Anas. Dicen que en una ocasión en que hicieron allí una

\footnotetext{
1 El presente trabajo se ha realizado dentro del proyecto de investigación HAR2012-32881, Manuscritos epigráficos españoles de los siglos XVI-XIX: entre la Historiografía y la Epigrafía científica, otorgado por la Secretaría de Estado de Investigación, Desarrollo e Innovación del Gobierno de España.

2 Francisco Marco Simón, "Acerca de las migraciones célticas a la Península Ibérica", en F. Marco, F. Pina y J. Remesal (eds.), Vivir en tierra extraña: emigración e integración cultural en el mundo antiguo, Barcelona, Universitat de Barcelona, 2004, págs. 78-79 (Col. Instrumenta, núm. 16); Alfredo González Ruibal, Galaicos. Poder y comunidad en el Noroeste de la Península Ibérica (1200 a. C. - 50 d. C.), A Coruña, Museu Arqueolóxico e Histórico da Coruña, 2006-2007, págs. 462-463 (Brigantium, 19).
} 
campaña militar éstos junto con los túrdulos, se sublevaron tras pasar el río Limea, y que luego de la revuelta, como sobreviniera la pérdida de su jefe, permanecieron en el lugar dispersos; y por esto es por lo que el río sería llamado Olvido3.

La confirmación de las afirmaciones de Estrabón de que algunas comunidades célticas y túrdulas realmente habitaban regiones costeras del noroeste de Hispania venía dada también por Mela quien, describiendo la costa lusitana al norte del Tajo, afirmaba que desde los cabos situados en el entorno de Olisipo (Lisboa) hacia el Duero se abría una gran curvatura y en ella estaban "los túrdulos y las ciudades de los túrdulos"4. Mela precisaba además que, desde el Duero hasta el promontorio Céltico, los celtas habitaban toda la región, exceptuando el área más al sur desde el Duero hasta el territorio de los grovios. También citaba los apelativos de estos pueblos célticos del noroeste, como los praestamarcos, los tamarcos y los neros, que serían los últimos o más norteños de toda esta región y se establecerían ya en el cabo Céltico ${ }^{5}$.

Plinio el Viejo hacía también referencia a los pueblos célticos del noroeste hispano, cuando afirmaba que el conuentus Lucensis era habitado por dieciséis pueblos poco importantes y de nombre bárbaro, excepto los célticos y los lemavos $^{6}$. Posteriormente hacía de nuevo referencia a las comunidades célticas afirmando, en sintonía con Mela, que en el cabo Céltico habitaban los celtas llamados neros y por encima los tamarcos, los coporos, la población de Noeta, los celtas llamados prestamarcos y los cilenos ${ }^{7}$. Los célticos praestamarci y los tamarci estaban situados en torno al río Tamaris, el actual Tambre, que desemboca en la ciudad de Noia (A Coruña). En cuanto a los túrdulos, Plinio, como Mela, los situaba junto a la desembocadura del Duero, cuando afirmaba que el río Durius separaba a los galaicos de Lusitania y asimismo, a los túrdulos de los bracarenses precisando, además, que a partir del Durius comenzaba Lusitania, donde habitaban los turduli ueteres ${ }^{8}$.

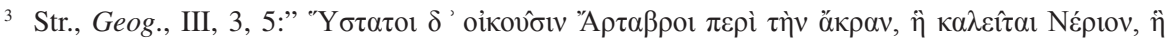

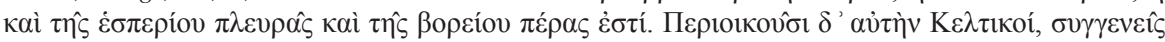

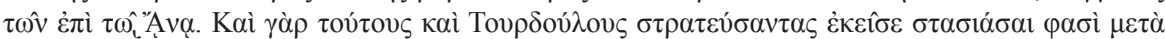

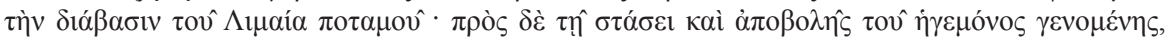

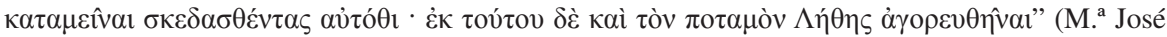
Meana y Félix Piñero, Estrabón. Geografía, libros III-IV, Madrid, Gredos, 1992, pág. 82).

4 Mela, III, $1,8$.

5 Mela, III, 1, 10-12.

6 Plin., nat., III, 28.

7 Plin., nat., IV, 111.

8 Plin., nat., IV, 112-113.
} 
Estas referencias de los autores antiguos a los célticos del extremo noroeste y a los túrdulos que habitaban junto al Duero han sido confirmadas por los registros epigráficos. Así, conocemos varias estelas funerarias de célticos supertamarcos que emigraron desde la costa galaica a las minas de oro de El Bierzo (León) en época altoimperial y acabaron su vida en Asturica Augusta o en sus cercanías, dado que tres estelas de estos celtici se hallaron en Astorga (León) ${ }^{9}$ y una en Santa Colomba de Somoza (León) ${ }^{10}$. Otra estela funeraria apareció más cerca del territorio de origen de estos célticos, en Lucus Augusti (Lugo), referente a una celtica supertamarca del castellum Miobri, que podría hacer referencia a un castro de la provincia de A Coruña, habida cuenta de que meobrigo se cita como apelativo de una deidad venerada en un ara votiva hallada en esa provincia ${ }^{11}$. Finalmente, también relacionaría el territorio noroeste de Hispania con los célticos el nombre de un arciprestazgo existente desde el año 1100 d.C., perteneciente a la diócesis de Santiago de Compostela, llamado Céltigos ${ }^{12}$.

En cuanto a los túrdulos, está también confirmada su presencia al sur de la desembocadura del Duero a partir de los registros epigráficos, puesto que conocemos dos téseras de hospitalidad halladas en el castro de Monte Murado o de Nossa Senhora da Saúde (Pedroso, Vila Nova da Gaia), que se datan en los años

\footnotetext{
$91^{\text {a) }}$ Su nombre está desaparecido, pero consta su origo celticus supertamarcus: CIL II 2904; CIL II 5081; Tomás MaÑanes, Epigrafía y numismática de Astorga romana y su entorno, Salamanca, Universidad de Salamanca, 1982, núm. 38; Francisco Diego Santos, Inscripciones romanas de la provincia de León, León, Institución Fray Bernardino de Sahagún, Diputación Provincial de León, 1986, núm. 102; Manuel Abilio Rabanal Alonso y Sonia María García Martínez, Epigrafía romana de la provincia de León. Revisión y actualización, León, Universidad de León, 2001, núm. 248; HEp 11, 281; 2a) Claicinus Clari filius, celticus supertamarcus: AE 1976, 286; T. MAÑanes, Epigrafía y numismática ..., núm. 39; F. Diego Santos, Inscripciones..., núm. 104; M.A. RABAnal Alonso y S.M. García Martínez, Epigrafía romana..., núm. 140; $3^{\text {a) }}$ Fusca Coedi filia, celtica supertamarca del castellum Elaniobrensis: CIL II 2902; CIL II 5667; T. MAÑANES, Epigrafía y numismática..., núm. 37; F. Diego Santos, Inscripciones..., núm. 109; M.A. Rabanal y S.M. García Martínez, Epigrafía romana..., núm. 170.

${ }^{10}$ Eburia Calueni filia, celtica supertamarca del castellum Lubri: M.A. Rabanal Alonso y S.M. García Martínez, Epigrafía romana..., núm. 153; HEp 7, 388; AE 1997, 873. El nombre del castellum podría hacer referencia al actual Lubre, en el concello de Bergondo (A Coruña).

${ }^{11}$ Apana Ambolli filia, celtica supertamarca del castellum Miobri (Antonio Rodríguez ColmeNERo, "Sobre dos nuevas estelas monumentales de Lucus Augusti", en F. Villar y F. Beltrán (eds.), Pueblos, lenguas y escrituras en la Hispania prerromana, Salamanca, Universidad de Salamanca e Institución "Fernando el Católico", de la Excma. Diputación de Zaragoza, 1999, págs. 606-611; AE 1997, 863; HEp 7, 397). Sobre la posible ubicación del castellum y la referencia al apelativo teonímico Meobrigo, uid., Blanca María PrósPer, Lenguas y religiones prerromanas en el Occidente de la Península Ibérica, Salamanca, Universidad de Salamanca, 2002, pág. 226.

${ }^{12}$ Francisco Javier GonZález García, "Los célticos de Gallaecia: apuntes sobre etnicidad y territorialidad en la Edad del Hierro del Noroeste de la Península Ibérica”, Complutum, 22 (2011), pág. 123 , fig. 3 .
} 
7 y 9 d.C. y que citan a individuos pertenecientes a la comunidad de los turduli ueteres ${ }^{13}$.

En cuanto al territorio del que, según Estrabón, procedían los célticos y los túrdulos del noroeste, las orillas del Anas, está también suficientemente testimoniado su poblamiento por célticos y túrdulos, que ocupaban toda una región conocida como Beturia, situada entre los ríos Betis y Anas. Los célticos ocupaban, además, algunas áreas situadas al oeste del Anas.

El territorio de la Beturia céltica se situaba en la parte sur-occidental de la actual provincia de Badajoz y norte de Huelva, ocupando las cuencas del Ardila, Alcarrache y la ribera izquierda del Guadiana ${ }^{14}$. Esta ubicación se confirma también por la enumeración de las ciudades de la Beturia de los célticos que, ya en el siglo I d.C., llevó a cabo Plinio. Para Beltrán, las ciudades de la Beturia Céltica que citaba Plinio serían las situadas al norte u oeste del Guadalquivir, es decir, Seria, Nertobriga, Segida, Ugultunia y Curiga, Lacinimurga y, finalmente, Arucci y Turobriga ${ }^{15}$.

La Beturia túrdula estaba situada al Este de la anterior, en los valles del Zújar, Matachel y ribera sur del Guadiana medio ${ }^{16}$. Esta comarca habría tenido una gran importancia estratégica para los romanos, funcionando durante los primeros siglos de la conquista como barrera frente a los pueblos de Lusitania y como núcleo de control de las riquezas mineras de la zona ${ }^{17}$. En cuanto a su carácter étnico, Untermann veía diferencias entre los túrdulos betúricos y los del sur del

\footnotetext{
${ }^{13}$ Armando Coelho Ferreira Da Silva, "As tesserae hospitalis de Castro de Senhora de Saude ou Monte Murado (Pedroso V. N. Gaia). Contributo para o Estudio da institucões o povoamento da Hispania Antigua", Gaia, 1 (1983), págs. 14-17; AE 1983, 476 y AE 1983, 477; Amílcar Guerra, Plínio-o-Velho e a Lusitânia, Lisboa, Ed. Colibrí, 1995, pág. 55 y 79 ss.

${ }^{14}$ Alonso Rodríguez Díaz, "Sobre la periferia turdetana y la configuración diversa de la Beturia prerromana. Célticos y túrdulos en el Guadiana medio", SPAL, 2 (1993), pág. 245.

${ }^{15}$ Francisco Beltrán Lloris, "Plin. NH II 13-14 ¿Beturia Céltica o Convento Hispalense? A propósito de la estructura de la descripción pliniana de la Bética", en III Congreso Peninsular de Historia Antigua, Vitoria, Biblioteca Digital Hiberus, Universidad de Zaragoza, 1994, págs. 413-426; José Luis Ramírez SÁDABa no considera Turobriga y Lacinimurga, en "Integración onomástica y social de los indígenas de la Beturia Céltica", Palaeohispanica, 9 (2009), pág. 215.

${ }^{16}$ A. RodríGuez DíAz, "Sobre la periferia...", pág. 251; Alonso RodRíGUEz DíAz, "Territorios y etnias prerromanas en el Guadiana medio: aproximación arqueológica a la Beturia túrdula", en A. Velázquez y J.J. Enríquez (eds.): Celtas y túrdulos: la Beturia, Mérida, Museo Nacional de Arte Romano y Asociación de Amigos del Museo, 1995, págs. 221-222 y 232 (Cuadernos Emeritenses, 9).

${ }^{17}$ Luis Berrocal-Rangel, Los pueblos célticos del suroeste de la Península Ibérica, Madrid, Universidad Complutense, 1992, pág. 66 (serie Complutum Extra, 2); Javier BermeJo MelÉndez, Un modelo de implantación territorial y municipal en la Baeturia Celtica: Arucci/Turobriga, civitas et territorium, Tesis Doctoral leída el 19 de noviembre de 2010, Huelva, Universidad de Huelva, 2011, pág. 161.
} 
Guadalquivir pues, mientras los topónimos y antropónimos de éstos son de origen ibérico o tartésico, los de los túrdulos de la Beturia eran hispano-celtas ${ }^{18}$.

\section{LA FUNDAMENTACIÓN HISTÓRICA Y LA CRONOLOGÍA DE LA MIGRACIÓN EN LA HISTORIOGRAFÍA}

La mayor parte de los autores que han estudiado la migración de célticos y túrdulos de la Beturia hacia el noroeste han aceptado que ésta tuvo lugar tal como la menciona Estrabón y habría tenido como consecuencia el establecimiento en la región de las comunidades célticas de los praestamarci, los supertamarci, los neri, los $a r t a b r i^{19} \mathrm{y}$, en torno al Duero, los turduli ${ }^{20}$, pero el verdadero problema para otorgar seguridad a ese acontecimiento radica en situar cronológicamente el desplazamiento de población y establecer su contexto histórico.

En cuanto a su cronología, algunos autores han propuesto para el noroeste peninsular una celtización progresiva o acumulativa, cuyo origen estaba en un sustrato "proto-celta" del Bronce Atlántico pero, aunque eran conscientes de la dificultad de detectar migraciones como la que citaba Estrabón, no descartaban que pudieran haberse producido desplazamientos de rango menor, como el que nos ocupa, en el interior de zonas previamente celtizadas ${ }^{21}$.

\footnotetext{
18 Jurgen UntermanN, "Célticos y túrdulos”, Palaeohispanica, 4 (2004), págs. 205-207.

19 Antonio García y Bellido, "Pequeñas invasiones y transmigraciones internas", AEArq. 23 (1951), pág. 493; Alain Tranoy, La Galice romaine. Recherches sur le nord-ouest de la péninsule Ibérique dans l'Antiquité, Paris, de Boccard, 1981, pág. 59; Pilar CIPRÉs, Guerra y sociedad en la Hispania indoeuropea, Vitoria, Universidad del País Vasco, 1993, pág. 57 (Anejos Veleia, serie minor); J. Untermann, "Célticos...", pág. 204; Alberto J. Lorrio Alvarado, "Los celtas en el occidente de Iberia", en Gonzalo Ruiz Zapatero y Jesús Álvarez-Sanchís (eds.), Castros y verracos. Las gentes de la Edad del Hierro en el occidente de Iberia, Ávila, Institución Gran Duque de Alba, Diputación de Ávila, 2011, pág. 50.

${ }^{20}$ A. García y Bellido, "Pequeñas invasiones...", págs. 494-495; Jorge Alarcão, "Etnogeografía da Fachada Atlântica Ocidental da Península Ibérica", Complutum, 2/3 (1992), pág. 344; Armando Coelho Ferreira Da Silva, "A evolução do hábitat castrejo e o proceso de proto-urbanização no noroeste de Portugal durante o I milénio a.C.", Revista da Facultade de Letras. Historia, 12 (1995), pág. 513; A.J. Lorrio Alvarado, "Los celtas...”, pág. 50.

${ }^{21}$ Martín Almagro-Gorbea, "El origen de los celtas en la Península Ibérica. Protoceltas y celtas", Polis. Revista de ideas y formas políticas de la Antigüedad Clásica, 4 (1992), pág. 23; A.J. LORRIO Alvarado, "Los celtas...", pág. 83. También Salinas aceptaba esta migración progresiva, aunque la de los célticos y túrdulos hacia el noroeste la situaba en época romana (Manuel SALINAS DE FRíAs, "Las fuentes clásicas y el poblamiento prerromano del occidente peninsular", en G. Ruiz Zapatero y J. Álvarez-Sanchís, eds.: Castros y verracos. Las gentes de la Edad del Hierro en el occidente de Iberia, Ávila, Institución Gran Duque de Alba, Diputación de Ávila, 2011, pág. 142, uid. infra.). Por otra parte, también habría existido una limitada colonización de la costa noroeste por otras comunidades durante el periodo orientalizante, cuyo origen, fenicio o tartésico, se discute. En este sentido, uid., Martín Almagro-Gorbea y Mariano Torres Ortiz, "La colonización de la costa atlántica de Portugal: ¿fenicios o tartesios?”, Palaeohispanica, 9 (2009), págs. 121 ss.
} 
Silva intentó establecer una datación algo más precisa para la migración, fijándola a mediados del I milenio, a partir de dataciones radiocarbónicas en el castro de Romariz (Santa $\mathrm{M}^{\mathrm{a}}$ da Feira, Aveiro) ${ }^{22}$, en el área de los turduli ueteres $\mathrm{y}$, paralelamente, en el castro de Borneiro (Coruña), que se enmarca en el área de los pueblos célticos del noroeste. Este autor se apoyaba también en la llegada de productos fenicios a la costa lusitana situada al sur del Duero durante ese período que, para él, habría estado ligada a la irrupción de los túrdulos y a otras migraciones internas peninsulares producidas a consecuencia de las transformaciones derivadas de la batalla de Alalia ${ }^{23}$.

González Ruibal, consciente de la dificultad de establecer una cronología muy definida, suponía que el desplazamiento se produjo en algún momento de la Segunda Edad del Hierro, entre el s. V y el II a.C. teniendo en cuenta, además, que a finales de ese período se habrían incrementado los fenómenos migratorios debidos a la conquista romana ${ }^{24}$.

Para Alarcão, la tesis de Silva no era del todo convincente y proponía la segunda mitad del s. III a.C., a consecuencia de la presión ejercida por los cartagineses y los celtíberos en el suroeste de la Península Ibérica ${ }^{25}$. Berrocal, en el mismo sentido, consideraba que la fecha de la expedición de grupos betúricos hacia el noroeste debía ser muy antigua, puesto que no se comprendía en un contexto del siglo I a.C ${ }^{26}$.

Para García y Bellido, el contexto de la migración se situaría en la segunda mitad del s. II a.C. por las convulsiones de las guerras lusitanas y celtibéricas, habida cuenta de que en el siglo I d.C., cuando escriben Estrabón, Mela y Plinio, aún no estaban consolidados en el territorio del noroeste peninsular los pueblos célticos, pues estaban en una "etapa aún emigrante", es decir, sin mezclarse con la población preexistente ${ }^{27}$.

Salinas opinaba que la migración se habría producido bajo dominio romano, teniendo en cuenta la datación de las monedas (89 al 40 a.C.) de la ceca de Tamusia en el castro de Villasviejas del Tamuja (Botija, Cáceres), que estaría poblado

\footnotetext{
${ }^{22}$ Armando Coelho Ferreira Da Silva, A cultura castreja no noroeste de Portugal, Paços de Ferreira, Museu Arqueológico da Citania de Sanfins, 1986, págs. 40-41.

${ }^{23}$ A. Coellho Ferreira Da Silva, A cultura castreja..., págs. 37 y 40; A. Coelho Ferreira Da SiLva, "A evolução...", págs. 508 y 513 (entre el 700 y 500 para los primeros niveles de Romariz y entre 620 y 420 para los de Borneiro); Armando Coelho Ferreira Da Silva, A cultura castreja no noroeste de Portugal ( $2^{a}$ edición), Paços de Ferreira, Museu Arqueológico da Citania de Sanfins y Centro de Arqueología Castreja e Estudos Célticos, 2007, pág. 41.

${ }^{24}$ También sobre los célticos del noroeste, A. González Ruibal, Galaicos..., págs. 465-466.

25 J. AlarCão, "Etnogeografía...", pág. 344.

${ }^{26}$ Luis Berrocal-RAngel, La Baeturia. Un territorio prerromano en la Baja Extremadura, Badajoz, Diputación de Badajoz, 1998, pág. 26.

${ }^{27}$ A. García y Bellido, "Pequeñas invasiones...", págs. 493-494.
} 
por gentes llegadas de Celtiberia. Para Salinas, de estas comunidades habrían partido los grupos que emigraron hacia el noroeste, aunque este desplazamiento podría ser la culminación de unos flujos migratorios mucho más antiguos. Además de esta propuesta, Salinas planteaba como sugerencia que la migración hacia el noroeste también podría haberse producido por la puesta en explotación de las minas de oro noroccidentales en época augustea ${ }^{28}$. Jordá Cerdá proponía también una fecha muy tardía para la llegada de los célticos hacia Gallaecia, afirmando que éstos habrían llegado ya como auxiliares de las legiones romanas $^{29}$.

Como vemos, existen enfoques diferentes y muchas dudas a la hora de dar una cronología a ese movimiento de poblaciones aunque, en realidad, ninguno de los investigadores citados tuvo como principal objetivo la solución al mismo.

Para fijar el acontecimiento será necesario analizar los contextos políticos y militares del territorio situado entre el Guadalquivir y el Guadiana y calibrar éstos con el registro arqueológico tanto de la Beturia como del noroeste peninsular. Sin embargo, comenzaremos nuestro análisis en los momentos posteriores a la Segunda Guerra Púnica, por varias razones. En primer lugar, el texto que nos transmite Estrabón sobre la migración nos ofrece el suficiente detalle como para suponer que no pudo haberse desarrollado en torno al s. V a.C., como planteaba Da Silva. No existe ningún acontecimiento histórico del territorio hispano que nos transmitan las fuentes literarias grecolatinas con esos detalles geográficos e históricos tan precisos desde el s. V a.C. hasta la llegada de los bárquidas a la Península Ibérica. En segundo lugar, dado que los datos de Estrabón están tomados de Posidonio, que escribió en torno a finales del s. II o principios del I a.C., y las referencias de Mela y Plinio son del s. I d.C., es destacable que se nombre a estos pueblos con sus denominaciones étnicas, como ya había observado García y Bellido ${ }^{30}$, reflejando una fase no demasiado lejana de su asentamiento en el territorio. Habida cuenta de estos argumentos, parece lógico fijar nuestro objetivo en los años posteriores a la $2^{\mathrm{a}}$ Guerra Púnica, en que los acontecimientos de Hispania podían ser registrados con cierta precisión por autores greco-romanos.

Por otra parte, hemos de tener presente que el valle del Guadiana es una región con importantes recursos minero-metalúrgicos y, en diversas áreas, con tierras muy fértiles. Por el contrario, las tierras costeras del noroeste hispano, donde se asentaron los célticos, ofrecen pocas posibilidades agrícolas. No ocurre lo mismo en la desembocadura del Duero pero, en cualquier caso, no es

\footnotetext{
${ }^{28}$ M. Salinas de Frías, “Las fuentes clásicas...”, pág. 142.

${ }^{29}$ Francisco JoRdÁ CERDÁ, "Notas sobre la cultura castreña del noroeste peninsular”, Memorias de Historia Antigua, 6 (1984), págs. 8-9. En el mismo sentido, Francisco Calo Lourido, A Cultura Castrexa, Vigo, A Nosa Terra, 1993, pág. 63.

30 A. García y Bellido, "Pequeñas invasiones...”, págs. 493-494.
} 
comparable a la fertilidad de las ricas riberas sedimentarias del Guadiana. Ya en época romana, cuando tenemos los primeros registros concretos de movimientos migratorios, vemos que la ribera del Anas no expulsaba población y, por el contrario, recibía numerosos inmigrantes. Por el contrario, Gallaecia enviaba población hacia otras áreas de Hispania, sobre todo hacia las minas de oro de El Bierzo (León) y hacia las minas de Rio Tinto (Huelva) ${ }^{31}$. Todo este contexto nos lleva a la convicción de que la migración de los célticos y túrdulos hacia el noroeste no tuvo causas estrictamente económicas y fue, probablemente, forzada por los ejércitos romanos durante la conquista del territorio hispano.

\section{El CONTEXTO POLÍTICO Y BÉLICO EN LA BETURIA: LA REBELIÓN DEL} AÑO I97 A. C.

El año 197 a.C. fue de gran importancia para la conquista romana de la Península Ibérica. Fueron nombrados pretores para la Hispania Ulterior Marco Helvio y para la Citerior Gayo Sempronio Tuditano ${ }^{32}$, pasando a disponer cada uno de 8.000 soldados de infantería y 400 jinetes proporcionados por los latinos y aliados para sustituir al antiguo ejército y, además, se encomendó a estos magistrados la delimitación y organización de las provincias hispanas ${ }^{33}$.

Cuando Helvio se había establecido en la Ulterior, envió una carta al senado, en la que se notificaba una rebelión en la Hispania Ulterior encabezada por dos régulos, Culchas y Luxinio. El primero era líder de diecisiete ciudades, mientras que Luxinio encabezaba las poblaciones de Carmo y Bardo. Además, según Livio, se podrían unir a la sublevación los malacitanos y sexetanos de la costa meridional, toda la Beturia y otras comunidades que aún no habían desvelado sus intenciones ${ }^{34}$.

Culchas había sido aliado de los romanos en el año 206, cuando las tropas de Escipión el Africano se enfrentaron en los alrededores de Ilipa a los cartagine$\operatorname{ses}^{35}$. En esta ocasión, Culchas era el líder de veintiocho poblaciones hispanas y

\footnotetext{
${ }^{31}$ Evan W. HaLey, Foreigners in Roman Imperial Spain: Investigations of Geographical Mobility in the Spanish Provinces of the Roman Empire 30 B.C.-A.D. 284, Diss. Columbia Univ., New York, Diss. Columbia Univ., 1986, págs. 207 y ss.

${ }^{32}$ Thomas R. S. Broughton, The Magistrates of the Roman Republic, vol. 1, New York, American Philological Association, 1951, pág. 333; Robert KNAPP, Aspects of the roman experience in Iberia. 206-100 B.C., Valladolid, Universidad de Valladolid, 1977, pág. 93; John S. Richardson, Hispaniae. Spain and the development of Roman imperialism, 218-82 BC., Cambridge, Cambridge University Press, 1986, pág. 181.

${ }^{33}$ Liv., 32, 28, 2 y 32, 28, 11.

${ }^{34}$ Liv., 33, 19, 6; 33, 21, 6; J.S. Richardson, Hispaniae..., págs. 76-77.

${ }^{35}$ Sobre las dudas sobre esa datación y la ubicación en Alcalá del Río, uid. J. S. Richardson, Hispaniae..., pág. 50.
} 
había aportado a los romanos un contingente de 3.000 infantes y 500 caballeros, que había reclutado durante el invierno anterior cumpliendo el compromiso que había adoptado con Escipión ${ }^{36}$.

En cuanto al otro cabecilla de la rebelión, Luxinio, cabe precisar que Luxia se llamó el río Tinto, que se situaba al sur de la Beturia céltica y el nombre de una de sus ciudades, Bardón, tiene la raíz Bard-, que se relaciona con los Bardu$l i$, otro nombre de los túrdulos ${ }^{37}$. Por tanto, dado que también aparecen citadas Carmo y toda la Beturia, parece que parte de la rebelión se centró en toda la región situada al oeste del Betis y entre este río y el Anas. Es verdad que los textos de Livio son escasos para que podamos precisar el alcance territorial de la sublevación del $197^{38}$, pero que "toda la Beturia" se hubiera rebelado parece una exageración puesto que, probablemente, los romanos todavía no habrían llegado al río Guadiana occidental ${ }^{39}$. En cualquier caso, el territorio de Luxinio, ubicado en torno a Carmo, que es una ciudad del Betis occidental y Bardo, que podría estar situada entre los túrdulos, enmarcaría el área más occidental del Betis y el área túrdula, lo que tendría continuidad con la Beturia.

En cuanto a Culchas, algunos autores le califican de celtíbero, sin fundamento ${ }^{40}$. Todo el contexto, tanto del año 206, cuando era aliado de Roma, como el

\footnotetext{
${ }^{36}$ Pol., Hist., 11, 20, 1-9; Liv., 28, 12, 10-15 y 28, 13, 1-9.

37 Adolf Schulten, Fontes Hispaniae Antiquae III. Las guerras de 237-154 a. de J.C., Barcelona, Universidad de Barcelona, 1935, pág. 175. En cuando a la raíz Bard- y los barduli, uid., Plin., nat., 4, 118. Según Thouvenot sería una ciudad de los célticos, no lejos de Carmo (Raymond ThouveNOT, Essai sur la province romaine de Bétique, Paris, de Boccard, 1973, pág. 106, n. 4). Para Untermann, podría ser una variante dialectal u ortográfica de uarduli, el pueblo prerromano del norte de la Celtiberia, lo que indicaría que parte de éstos habría migrado desde la Meseta Norte hacia la Beturia junto a los berones y otros celtíberos (J. Untermann, "Célticos...", págs. 206-207).

${ }^{38}$ Alan E. Astin, Scipio Aemilianus, Oxford, Clarendon Press, 1967, pág. 122. Según Montenegro, fue una "insurrección general...se sublevó prácticamente toda la Bética" (Angel Montenegro, "La conquista de Hispania por Roma (218-19 antes de Jesucristo)", en Historia de España R. Menéndez Pidal, t. II.1. La conquista y la explotación económica, Madrid, Espasa-Calpe, 1986, págs. 53-54). En el mismo sentido, Thouvenot afirmaba que únicamente las ciudades de la costa meridional, Gades y Carteia, no se habían sublevado (R. Thouvenot, Essai ..., pág. 107). Para Cadiou, en cambio, la rebelión del 197 no habría sido un conflicto generalizado, dada la pasividad con que el senado la acometió y la prontitud con que la rebelión decayó, en François CADIOU, Hibera in terra miles. Les armées romaines et la conquête de l'Hispanie sous la République (218-45 av. J.-C.), Madrid, Casa de Velázquez, 2008, pág. 34-35. La rebelión de Culchas se habría debido a la redefinición de los territorios tras la victoria romana ante los cartagineses y la consiguiente pérdida de poder del régulo, según Eduardo Pitillas, "Una aproximación a las reacciones indígenas frente al expansionismo romano en Hispania (205 al 133 a.n.e.)", Memorias de Historia Antigua, 17 (1996), pág. 135; en el mismo sentido, F. CADIOU, Hibera..., pág. 37, n. 40. A estos argumentos, Pitillas añade la creciente influencia del mercenario celtibérico en Turdetania (E. PitiLlas, "Una aproximación...", pág. 135).

${ }^{39}$ A.E. Astin, Scipio..., pág. 123, n. 75.

${ }^{40}$ E. Thouvenot, Essai..., págs. 106-107.
} 
de los acontecimientos del 197, le relacionan con Turdetania. Sin embargo, si el área encabezada por Culchas hubiera estado también en la región occidental de la Turdetania, habría que interpretar la rebelión de los sexetanos y los malacitanos, situada mucho más al Este, como aislada del foco de la revuelta. Esto es poco probable, sobre todo si tenemos en cuenta que, en los años posteriores, los núcleos del conflicto se sitúan, precisamente, en la región oriental de la Turdetania.

Las fuentes no dan pista alguna del desenlace ni precisan la evolución de la revuelta de Culchas ${ }^{41}$. Sin embargo, podríamos hacer una reconstrucción de los hechos que nos lleve a establecer su territorio de origen. En el 206, cuando Culchas colaboró con Escipión, éste se dirigía desde Tarraco hacia Castulo cuando hizo adelantarse a Marco Junio Silano para encontrarse con Culchas, con el fin de incorporar a los reclutas comprometidos por éste y dirigirse con ellos a los alrededores de Cástulo. Teniendo en cuenta que toda la Turdetania occidental estaba en ese momento en manos de los cartagineses, el ámbito en el que Culchas podía ejercer su liderazgo sólo podía situarse en la Turdetania oriental y la Bastetania ${ }^{42}$. Por ello, en primer lugar, también se rebelaron en el 197 las ciudades costeras de Malaca y Sexi que, de este modo, se situaban en el entorno del territorio encabezado por Culchas. Si tenemos en cuenta esta idea, sí que podemos observar una evolución en los acontecimientos, puesto que los conflictos de los años posteriores en Turdetania continúan en esta región, al sur de Castulo e Iliturgi hasta el mar.

Por tanto, aunque las fuentes no precisan la continuidad de la rebelión de Culchas, los acontecimientos subsiguientes nos permiten fijar ese territorio. Cuando Marco Helvio en el año 195, abandonaba su provincia camino de Roma con una escolta de 6.000 soldados, se encontró con una fuerza de 20.000 celtíberos en los

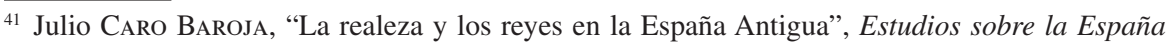
Antigua. Cuadernos de la Fundación Pastor, 17 (1971), pág. 130.

${ }^{42}$ Arturo Ruiz Rodríguez, "El concepto de clientela en la sociedad de los príncipes", en C. Mata Parreño y G. Pérez Jordà (eds.), Ibers. Agricultors, artesans i comerciants. III Reunió sobre Economia en el Món Ibèric, Valencia, 2000, pág. 13 (Saguntum extra-3), lo situaba al sur del alto Guadalquivir, seguido por Fernando Quesada, "La guerra en las comunidades ibéricas (c. 237-c. 195 a.C.): un modelo interpretativo", en A. Morillo, F. Cadiou y D. Hourcade (eds.), Defensa y Territorio en Hispania de los Escipiones a Augusto, coloquio celebrado en la Casa de Velázquez (19 y 20 de marzo de 2001), León, Universidad de León, Secretariado de Publicaciones y Medios Audiovisuales y Casa de Velázquez, 2003, pág. 120, n. 57. Por el contrario, J. Caro Baroja, "La realeza...", pág., 131, ubicaba los territorios de Culchas "más a Occidente" y Luís Agustín García Moreno, "Ciudades béticas de estirpe púnica (un ensayo postmarxista)", Dialoghi di Archeologia, 10 (1992), pág. 126, los colocaba en la Beturia y Andalucía occidental.
} 
alrededores de Iliturgi. Según Livio, habrían muerto en el enfrentamiento 12.000 enemigos y Helvio acabó tomando la ciudad y ejecutando a todos sus jóvenes ${ }^{43}$.

Ese mismo año, el pretor de la Citerior Publio Manlio se encontraba en Turdetania $^{44}$, enfrentado a los turdetanos y a los celtíberos que aquéllos habían contratado como mercenarios y decidió solicitar la ayuda del cónsul Marco Porcio Catón. Ya en el 194, el cónsul se dirigió al sur pero, dado que éste no consiguió atraer a los enemigos a la batalla, regresó al norte del Ebro ${ }^{45}$. En el 192, el procónsul Marco Fulvio Nobilior ${ }^{46}$ había conquistado dos plazas fuertes de la Hispania Ulterior oriental, Vescelia y Elo, antes de dirigirse a Carpetania, donde tomó la ciudad de Toletum ${ }^{47}$.

La hostilidad existente en algunas comunidades de esta región hacia los romanos permitiría comprender la irrupción de los lusitanos en la misma y su control de algunas ciudades. Entre los años 190-189, el procónsul Lucio Emilio Paulo $^{48}$ se había enfrentado a los lusitanos en Licón, población de la Bastetania, donde perdió 6.000 hombres, aunque ya en el 189, antes de llegar su sucesor, realizó otra campaña contra los lusitanos, consiguiendo la victoria ${ }^{49}$, aunque finalmente murió durante estas batallas ${ }^{50}$.

En el ámbito occidental, que habría estado vinculado en el 197 a la revuelta de Luxinius, quizá por ser un territorio fronterizo, no se llevaron a cabo operaciones bélicas de tanta entidad en los años posteriores. Sin embargo, en el 194 Publio Cornelio Escipión tuvo que enfrentarse a los lusitanos, que estaban llevando a cabo campañas de saqueo en Turdetania y les venció cerca de Ilipa, donde les arrebató su botín y forzó su huída ${ }^{51}$. Pocos años después, en 188-187, llegaron de las provincias hispanas dos tribunos militares a Roma, según Livio, con cartas de los pretores de la Ulterior, Gayo Atinio, y de la Citerior, Lucio Manlio Acidino $^{52}$, que anunciaban que los celtíberos y los lusitanos estaban sublevados

\footnotetext{
${ }^{43}$ Liv., 34, 10. Su salida se habría retardado más de un año por una enfermedad, llegando a Roma sólo dos meses antes que su sucesor.

44 T.R.S. Broughton, The magistrates... (vol. I), pág. 340.

${ }^{45}$ Liv., 34, 19. Algunos autores, teniendo en cuenta el conflictivo contexto en el noroeste, opinan que Catón no se habría dirigido a Turdetania, sino al territorio de los turboletas (A.E. Astin, Scipio..., pág. 123).

46 T.R.S. Broughton, The magistrates... (vol. I), pág. 351.

${ }^{47}$ Liv., 35, 22, 6. La ciudad de Elo podría ser la que aparece en las monedas como Halos, en los alrededores de Iliturgi.

48 T.R.S. Broughton, The magistrates... (vol. I), pág. 357.

${ }^{49}$ Liv., 37, 46, 7.

${ }^{50}$ Oros., 4, 20, 23.

51 Liv., 35, 1, 3.

${ }^{52}$ T.R.S. Broughton, The magistrates... (vol. I), pág. 365.
} 
y devastaban el territorio de los aliados ${ }^{53}$. Atinio habría tenido que enfrentarse a los lusitanos en Hasta, donde murieron 6.000 enemigos y después tomó al asalto la propia ciudad, donde encontró la muerte ${ }^{54}$. Todo parece indicar, por tanto, que durante el cargo de su sucesor, Gayo Calpurnio Pisón (186-185), se consiguió pacificar esta parte occidental del territorio bético puesto que éste concentró sus tropas en primavera junto a las del pretor de la Citerior, Lucio Quincio Crispino, en la Beturia antes de partir al norte hacia Carpetania ${ }^{55}$.

En resumen, aunque la revuelta en la Beturia contra Roma del 197 habría debido suponer sucesivas campañas punitivas contra las ciudades del territorio, lo cierto es que las fuentes nos dicen poco. Únicamente se nos relatan los conflictos con los lusitanos cuando éstos irrumpen en Turdetania, en lo que parece ser una política de corte defensivo por parte de Roma y, en cualquier caso, el avance fue muy lento e indeciso hasta el 155 en toda la región ${ }^{56}$. Por tanto, aun suponiendo que se hubieran realizado operaciones bélicas en el área, el contexto que transmiten las fuentes durante los conflictos del 197-195 y las décadas posteriores no permite concluir que pudieran haber derivado en un movimiento migratorio de comunidades betúricas hacia el noroeste peninsular.

\section{LOS CONFLICTOS BÉLICOS DE MEDIADOS DEL S. II A. C. EN LA REGIÓN BETÚRICA}

Los conflictos que acontecieron hacia la mitad del siglo II a.C., en el contexto de las guerras lusitanas, tuvieron un mayor impacto en el territorio betúrico que los acontecimientos de principios de siglo. Debemos, sin embargo, hacer algunas precisiones para poder fijar el marco de los acontecimientos con claridad.

En primer lugar, hemos de comentar la hipótesis de Berrocal-Rangel, quien establecía la datación del abandono del nivel III de Castrejón de Capote (Higuera la Real, Badajoz) y, a su vez, el cese de la utilización del altar hallado en el castro a causa de la toma de Nergobriga por Marcelo en el año 152 a.C ${ }^{57}$. Esta

\footnotetext{
${ }^{53}$ Liv., 39, 7, 6.

${ }^{54}$ Liv., 39, 21, 1-4. Hay que tener en cuenta que estos hechos sucedieron un año después de que Emilio Paula llevara a cabo las medidas organizativas en el entorno de Hasta y la Turris Lascutana (CIL II 5041).

55 Liv., 39, 30, 1-2. T.R.S. Broughton, The magistrates... (vol. I), pág. 371

56 A. Montenegro, "La conquista...", pág. 60; Andrew Lintott, "The Roman Empire and its problems in the late second century", The Cambridge Ancient History, vol. IX, The last age of the Roman Republic, 146-43 B.C., Cambridge, Cambridge University Press, 1992, págs. 20-21; Catherine SteEl, The end of the Roman Republic, 146 to 44 B.C. Conquest and crisis, Edimburgo, Edinburgh University Press, 2013, pág. 10.

57 Pol., Hist., 35, 2, 1-2; Adolf Schulten, Fontes Hispaniae Antiquae IV. Las guerras de 154-72 a. de J.C., Barcelona, Universidad de Barcelona, 1937, pág. 19; P. CiPrés, Guerra..., pág. 77. Luis
} 
supuesta conquista plantea, sin embargo, muchos problemas y posibles errores. Hay que tener en cuenta que en el texto de Polibio que cita la expedición de Marcelo hacia la Ulterior estaba escrito Erkobrika, que Schweighaeuser reconstruyó como Nerkobrika ${ }^{58}$, mientras que la Nergobriga que cita Apiano también como conquista de Marcelo estaba en la Citerior, en territorio arévaco ${ }^{59}$. Es muy extraño, por tanto, que el procónsul de la Citerior Marcelo atacara el mismo año dos ciudades llamadas Nergobriga, cada una de ellas en una provincia hispana, siendo los hechos transmitidos por autores distintos y, además, con uno de los textos restituido.

Según Richardson, o bien dicha restitución de Schweighaeuser debe ser rechazada, y la ciudad de la Ulterior era otra Erkobrika cuya localización se desconoce, o bien la restitución era correcta y, simplemente, o Polibio o Apiano habían ubicado la ciudad en la provincia equivocada ${ }^{60}$. En este sentido, la referencia de Polibio a la Ulterior es aislada y no tiene ninguna relación con el resto de los acontecimientos en los que se ve envuelto Marcelo y, por el contrario, los acontecimientos relativos a la Nergobriga celtibérica son fundamentales para el contexto histórico general y son narrados con todo detalle: establecen tratados con Marcelo apenas éste ocupa su puesto en la Citerior; el pretor vincula cualquier trato con esta ciudad a que sea ampliado a los arévacos, belos y titos; finalmente, ante posibles acuerdos secretos de Marcelo con los nergobrigenses, los arévacos toman la ciudad ${ }^{61}$. En definitiva, la toma de la supuesta Nergobriga de la Hispania Ulterior por Marcelo es extremadamente dudosa ${ }^{62}$, lo que aconseja no utilizar ese dato para contextualizar niveles de abandono en el santuario de Castrejón de Capote. Sin embargo, como veremos a continuación, sí se justifican esos niveles de abandono en el contexto político militar que acontece pocos años más tarde, cuando los asedios y conquistas de las ciudades betúricas son más frecuentes y destructivos.

Los hechos más destacables que podrían estar en el origen de los desplazamientos de las comunidades betúricas hacia al noroeste de Hispania se produjeron poco después, a partir del año 141 a. $C^{63}$. En este año, el procónsul Fabio

Berrocal-Rangel, "El asentamiento «céltico» del Castrejón de Capote (Higuera la Real, Badajoz)", CuPAUAM 16 (1989), pág. 257, la relaciona con la Nertobriga de época cesariana, que se ubicaría en la Beturia céltica, a pesar de la diferencia ortográfica con la citada por Polibio.

58 J.S. Richardson, Hispaniae..., pág. 196.

${ }^{59}$ App., Iber., 48.

${ }^{60}$ J.S. Richardson, Hispaniae..., pág. 196. A. Montenegro, "La conquista...", pág. 89, ya dudaba si el texto de Polibio se refería a la celtibérica o a la que cita Plinio en la Bética.

${ }^{61}$ App., Iber., 48-50.

62 J.S. Richardson, Hispaniae..., pág. 196.

${ }^{63}$ Jean-Gerard Gorges y Francisco Germán RodríGuez MARTín, "Les guerres lusitaniennes entre mythe, histoire et réalité: réflexions autour du complexe militaire romain du «Pedrosillo» (Casas de 
Máximo Serviliano llegó como sucesor de Quincio en el mando proconsular a la Hispania Ulterior, con unas fuerzas de dieciocho mil soldados de infantería y mil seiscientos jinetes ${ }^{64}$. El pretor se dirigió a Itucci, donde fue atacado por Viriato. Con la ayuda de contingentes africanos enviados por Micipsa, consiguió poner en fuga a los lusitanos pero, ante el contraataque de éstos, Serviliano se refugió en Itucci $^{65}$. Viriato se retiró a Lusitania y es entonces cuando Serviliano, no pudiendo alcanzarle, invadió la Beturia y saqueó cinco ciudades que se habían puesto de parte de Viriato. A continuación, el pretor hizo una campaña contra los cuneos y, desde allí se dirigió, de nuevo, hacia territorio lusitano. Apiano cuenta que, mientras estaba de camino, Curio y Apuleyo, dos cabecillas de bandoleros, le atacaron con diez mil hombres y le arrebataron el botín ${ }^{66}$. Curio fue derrotrado y Serviliano recuperó su botín, tomando posteriormente las ciudades de Escadia, Gemella y Obolcola, que contaban con guarniciones establecidas por Viriato ${ }^{67}$. Livio nos relata, además, que Serviliano saqueó más ciudades y perdonó a otras. Habiendo apresado a diez mil enemigos, cortó la cabeza a quinientos de ellos, y vendió al resto. Después de apresar a Connoba, otro capitán de latrones que se le rindió, le perdonó sólo a él, pero cortó las manos a todos sus hombres ${ }^{68}$.

reina, Badajoz, Espagne)", en J.G. Gorges, J. d' Encarnação, T. Nogales Basarrate y A. Carvalho (coords.), Lusitânia romana - entre o mito e a realidade. Actas da VI mesa-redonda internacional sobre a Lusitânia romana, Cascais, Camara Municipal de Cascais, 2009, pág. 369, consideraban que la fase 141-139 a.C. fueron los años decisivos de las guerras lusitanas, en los que se produjeron las grandes campañas en la Beturia.

${ }^{64}$ T.R.S. Broughton, The magistrates... (vol. I), págs. 477-478; J. S. Richardson, Hispaniae..., págs. 184 ss.

${ }^{65}$ Según A. Schulten, Fontes... (IV), pág. 116, esta Itucci sería Tucci, es decir, Martos (Jaén). En el mismo sentido, A. Montenegro, "La conquista...”, pág. 97; J. G. Gorges y F. G. Rodríguez MARTín, "Les guerres...”, pág. 371.

${ }^{66}$ Hans G. Gundel, "Viriato, Lusitano, caudillo en las luchas contra los romanos. 147-139 antes de Cristo”, Caesaraugusta, 31-32 (1968), pág. 186; E. Thouvenot, Essai..., págs. 127-128.

${ }^{67}$ Escadia podría ser Astigi (A. Schulten, Fontes...IV, pág. 119; H. G. Gundel, "Viriato...”, pág. 186; E. Thouvenot, Essai..., pág. 128; A. Montenegro, “La conquista...”, pág. 98; R. Knapp, Aspects..., pág. 18); Gemella se identifica con Tucci (Martos, Jaén) (A. Schulten, Fontes...IV, pág. 119; H. G. Gundel, "Viriato...”, pág. 186; E. Thouvenot, Essai..., pág. 128; A. MonteneGRO, "La conquista...", págs. 97-98; R. KNAPP, Aspects..., pág. 18) y Obolcola (Plin., nat., III, 12) con Obulco (Porcuna, Jaén) (H. G. Gundel, "Viriato...”, pág. 186; R. Knapp, Aspects..., pág. 18), aunque ello no es posible, ya que Porcuna está muy hacia el este de Astigi y el Itinerario de Antonino sitúa Obolcola entre Hispalis y Astigi $(413,2)$ y entre Carmo y Astigi $(414,3)$, por lo que estaría en las cercanías de La Monclova, 15 millas romanas $(22 \mathrm{~km}$ ) al oeste de Astigi (Écija, Sevilla) y 42 millas $(62 \mathrm{~km})$ al este de Hispalis (Sevilla). Esto es del todo coherente con el Ravennate (315, 4) y los vasos de Vicarello, donde se cita como Obulcla. En este sentido, uid. Juan Luis GARcía Alonso, La Península Ibérica en la Geografía de Claudio Ptolomeo, Vitoria, Universidad del País Vasco, 2003, pág. 72 (Anejos Veleia serie minor).

${ }^{68}$ App., Iber., 67-68 
Serviliano, después de una sucesión de victorias, se encontró con graves dificultades en una de sus campañas en 141 y hubo de llevar a cabo un pacto de urgencia con Viriato que pudo poner fin al conflicto, reconociendo la hegemonía del líder lusitano sobre algunas ciudades situadas entre el Guadalquivir y el Guadiana $^{69}$. El pacto fue ratificado en Roma, pero fue impugnado por Servilio Cepión, hermano de Serviliano y su sucesor en el proconsulado de la Ulterior en $139^{70}$, y el senado autorizó la continuación de la guerra ${ }^{71}$.

Con este apoyo, Cepión conquistó la ciudad de Erisana, abandonada por Viriato $^{72}$. El hecho de que esta ciudad hubiera estado en manos de los lusitanos durante el período de tregua indicaría que algunas partes de la Beturia todavía permanecían en manos de Viriato, independientemente de la discusión sobre la identificación de esta ciudad con Arsa, citada por Plinio y Apiano, que se ubicaba en la Beturia de los túrdulos ${ }^{73}$.

La gran intensidad de las actuaciones de los ejércitos romanos en el área betúrica en estos años, se hace también patente en el descubrimiento de un campamento romano ubicado en el "Pedrosillo", en la Beturia túrdula. Se trata de un auténtico complejo militar con dos recintos amurallados, fortines y un sistema de defensas complementarias que ocupan más de 330 ha y que podrían haber acogido a una legión completa y sus unidades auxiliares. El campamento puede datarse a mediados del s. II a.C. o en la segunda mitad del siglo, aunque hay datos que inducirían a fijar su uso en el 140 a.C., teniendo en cuenta el desarrollo de los acontecimientos bélicos en ese área ${ }^{74}$. En cualquier caso, sabemos que

${ }^{69}$ R. KNAPP, Aspects..., págs. 42 y 53, resalta que Viriato no había rendido sus armas a raíz del pacto, por lo que era un tratado entre iguales, solución no habitual en las guerras hispanas durante esos años.

${ }^{70}$ T.R.S. Broughton, The magistrates..., pág. 482.

${ }^{71}$ Sobre este pacto, uid., H.G. Gundel, "Viriato...", págs. 186-189; R. KNAPP, Aspects..., págs. 42 ss.; F. CAdiou, Hibera..., pág. 50.

72 App. Iber., 70; H.G. GundEL, "Viriato...", págs. 189-190.

${ }^{73}$ Plin., nat., 3, 14; A.E. Astin, Scipio..., pág. 142, n. 4; José Manuel Roldán, La República Romana, Madrid, Cátedra, 2010, pág. 328; H.G. Gundel, "Viriato...", pág. 186; Ma Paz García Y BELlido, "Sobre las dos supuestas ciudades de la Bética llamadas Arsa. Testimonios púnicos en la Beturia túrdula", Anas 4-5 (1991-1992), pág. 82. La identificación de las ciudades Erisana y Arsa de Apiano (Ib., 69-70) no es segura y debe ser mantenida con cautela (A. SCHulten, Fontes... IV, pág. 119; E. Thouvenot, Essai..., pág. 128; A. Montenegro, "La conquista...", pág. 98; F. Cadiou, Hibera..., pág. 50, n. 112. Igualmente, J.G. Gorges y F.G. Rodríguez Martín, "Les guerres...", págs. 377-378, aunque prefieren considerarlas como dos enclaves distintos.

${ }^{74}$ Jean-Gerard Gorges y Francisco Germán Rodríguez Martín; "Un probable complejo militar romano de época republicana en la Beturia túrdula: notas preliminares sobre el campamento del "Pedrosillo" (Casas de reina, Badajoz)", en A. Morillo (coord.), Arqueología Militar Romana en Hispania: producción y abastecimiento en el ámbito militar (II Congreso Internacional de Arqueología militar romana en Hispania, León, 2004), León, Universidad de León, Ayuntamiento de León, 2006, págs. 657 y ss.; Jean-Gerard Gorges, Angel Morillo Cerdán, Francisco Germán Rodrí- 
desde el 140-139, Servilio Cepión pudo construir algunos enclaves fortificados al oeste y norte de la región betúrica, como indica la toponimia: Caepiana (Setúbal) y, posiblemente, Castra Servilia (cerca de Cáceres), aunque no es totalmente segura su fundación en época de este magistrado ${ }^{75}$.

Las guerras llevadas a cabo por Serviliano en el 141-140 y continuadas por Cepión, enmarcan un contexto que pudo ser la causa de migraciones de grandes grupos de población hacia el noroeste, por varias razones. En primer lugar, supone el conjunto de actuaciones bélicas más demoledor, intenso y continuado de políticas punitivas de los llevados a cabo por Roma en el territorio betúrico hasta ese momento ${ }^{76}$. En segundo lugar, el territorio de destino de la migración de las comunidades túrdulas y célticas se situaba fuera del ámbito controlado hasta ese momento por Roma en Hispania, es decir, el Noroeste era el único lugar seguro de la Península Ibérica al que habrían podido desplazarse grupos de población que se hubieran opuesto militarmente a los romanos, ya que éstos llegaron al noroeste algunos años más tarde, durante el consulado y proconsulado de Décimo Junio Bruto ${ }^{77}$. En tercer lugar, las consecuencias de la irrupción militar de Roma

guez Martín y Esperanza Martín Hernández; "Le campement romano-républicain du «Pedrosillo» (Casas de Reina, Badajoz, Espagne) à l'épreuve des sondages: premiers résultats de la campagne 2006", Limes 20, (XX Congreso Internacional de Estudios sobre Frontera Romana (León, 2006), vol. III, Madrid, 2009, págs. 267 y ss. (Gladius, anejos III, 2009). Los elementos arqueológicos de datación son, por el momento, varios clavos de hierro con paralelos en Numancia, también datables a mediados del s. II a.C. (ibid., pág. 278), pero igualmente son paralelos los caracteres morfológicos de estructuras campamentales, homologables con las de Renieblas y Aguilar de Anguita (J.G. Gorges y F.G. Rodríguez Martín, "Les guerres...”, pág. 368). Por otra parte, también el contexto histórico permite datar las estructuras en torno al 140 a.C. (J.G. GorGEs y F.G. Rodríguez Martín, "Les guerres...”, pág. 381).

${ }^{75}$ El sufijo - ana en neutro plural, sería indicativo de campamentos militares, por lo que habrían estado precedidos del término castra. Sobre estos enclaves y su función, Jorge Alarcão, Portugal romano, Lisboa, Verbo, 1974, págs. 34-35; A. Montenegro, "La conquista...”, págs. 98-100; F. CAdiou, Hibera..., págs. 282 ss. y R. KnApP, Aspects..., pág. 23, quien lo cita como Caepiona. Para E. Thouvenot, Essai..., pág. 129, Castra Servilia indicaría la ruta de las campañas de Cepión. En el mismo sentido, R. KNAPP, Aspects..., pág. 26. En cambio, esta identificación se puede asegurar en opinión de otros autores, como Antonio RodríGuez Colmenero, Galicia meridional romana, Bilbao, Universidad de Deusto, 1977, pág. 32 y F. CADiou, Hibera..., pág. 290, n. 57. De hecho, conocemos otro Servilio Cepión que celebra un triunfo sobre los lusitanos en 107 (E. THOUvENOT, Essai..., pág. 132, n. 3, con bibliografía).

76 A. Tranoy, La Galice..., pág. 126; J.M. Roldán, La República..., pág. 328; J.G. Gorges y F.G. Rodríguez Martín, “Les guerres...”, pág. 369 con fig. 8.

77 T.R.S. Broughton, The magistrates... (vol. I), págs. 483-485; J. Alarcão, Portugal..., págs. 35-38; Casimiro Torres Rodríguez, "La conquista romana de Galicia", en La romanización de Galicia. Cuadernos del Seminario de Estudios Cerámicos de Sargadelos 16, Sada-La Coruña, 1976, págs. 15-18; Casimiro Torres Rodríguez, La Galicia romana, A Coruña, Instituto de Estudios Gallegos Padre Sarmiento, 1982, págs. 25-26 (Colección Galicia Histórica); Narciso SaNTos YANGUAS, "La conquista romana del N.O. de la Península Ibérica”, Latomus, 41/1 (1982), págs. 10 
en el territorio betúrico muestran un panorama muy semejante al que ofrece Estrabón sobre la migración celto-túrdula en el noroeste, puesto que cita líderes, que Apiano llama bandoleros, encabezando grandes grupos de población que han quedado desvinculados de sus tierras y de sus comunidades de origen y que se desplazan por las fronteras exteriores del dominio romano. El simple hecho de que estos grupos abandonaran sus tierras para defenderse de la ocupación romana habría detenido la productividad de las mismas y habría provocado la pérdida de sus medios de subsistencia ${ }^{78}$, lo que se acentuaba si esas tierras eran ocupadas definitivamente por los romanos. En muchas ocasiones, ni siquiera eran poseedores de tierras, porque se trataba de comunidades ganaderas que eran originarias de regiones montañosas ${ }^{79}$. En cualquier caso, es lógico pensar que estos grupos se hubieran desplazado a territorios más seguros para obtener un lugar donde asentarse. Finalmente, sabemos que Cepión arrebató las armas a los lusitanos, pero tomó la decisión de entregar tierras a los vencidos y una ciudad donde pudieran establecerse ${ }^{80}$, medida que pudo llevarse a cabo con la fundación de Valentia durante las magistraturas de Junio Bruto en el 138-137 a.C. ${ }^{81}$, por lo que es lógico pensar que la migración de los célticos y túrdulos debió producirse antes de esta política parcialmente integradora.

Sayas insistía en que el bandolerismo era un fenómeno que ya existía en época prerromana, consecuencia de una propiedad desigual de la tierra que habría motivado que individuos de las capas sociales más pobres, desposeídas de recursos fundiarios, buscaran otros medios de vida, alistándose como mercenarios o practicando el bandolerismo ${ }^{82}$. Sobre estas tesis, otros autores añadían la radical

y ss.; Narciso Santos Yanguas, El ejército y la romanización de Galicia, Oviedo, Universidad de Oviedo, 1988, págs. 29-33; A. Montenegro, “La conquista...”, págs. 100-102.

78 Juan José SAYAs, "El bandolerismo lusitano y la falta de tierras", Espacio, Tiempo y Forma (HA) 4 (1989), págs. 702-703.

${ }^{79}$ P. CIPRÉs, Guerra...,págs. 141-146.

${ }^{80}$ App., Iber., 75; Diod., XXXIII, 1, 4; Ptol., 2, 5, 2; R. KNAPP, Aspects..., págs. 53-54.

${ }^{81}$ Liv., Per., 55. La ciudad está, por el momento, sin localizar (R. THouvenot, Essai..., págs. 130131; A. Rodríguez Colmenero, Galicia..., pág. 38; E. Pitillas, "Una aproximación...”, pág. 137). Francisco PINA Polo, "Deportaciones como castigo e instrumento de colonización durante la República romana: el caso de Hispania”, en F. Marco Simón, F. Pina Polo y J. Remesal Rodríguez, J. (eds.), Vivir en tierra extraña. Emigración e integración cultural en el mundo antiguo. Actas de la reunión realizada en Zaragoza los días 2 y 3 de junio de 2003, Barcelona, Universitat de Barcelona, 2004, págs. 231-232, opinaba que también Brutobriga habría sido una fundación para instalar a los lusitanos vencidos.

82 J. J. SAYAS, "El bandolerismo...”, págs. 702-704; Juan José SAYAs, “Algunas consideraciones sobre cuestiones relacionadas con la conquista y romanización de las tierras extremeñas", en $E l$ proceso histórico de la Lusitania oriental en época prerromana y romana, Mérida, Museo Nacional de Arte Romano, 1993, págs. 214 y ss. (Cuadernos Emeritenses, 7); A. Montenegro, "La conquista...", pág. 61; Manuel SALINAS DE FRÍAS, "Problemática social y económica del mundo indígena lusitano", en El proceso histórico de la Lusitania oriental en época prerromana y romana, Méri- 
transformación que sufrió el mundo indígena en el sur de Lusitania y la Beturia durante el largo período de guerras contra los romanos, que habría incrementado radicalmente las diferencias sociales y habría arruinado las bases económicas de estos pueblos ${ }^{83}$.

Otros autores resaltan la existencia de cofradías de guerreros o bandas institucionalizadas que practicaban la deuotio hacia un líder ${ }^{84}$ y que vivían al margen de la sociedad abandonando sus poblaciones y saqueando ciudades y territorios ricos del entorno. Era una tradición secular en el mundo lusitano, que se vinculaba a rituales de paso y a pruebas iniciáticas de valor personal y que se extendía por todo el territorio europeo ${ }^{85}$. Estas fratrías guerreras, de origen indoeuropeo, no eran específicas del ámbito lusitano ${ }^{86} \mathrm{y}$, sin embargo, aparecen en torno al s. II a.C. sobre todo en este ámbito, por lo que cabe pensar que las causas del bandolerismo tendrían más relación, en este caso, con las especificidades socio-económicas de estas regiones, sin perjuicio de que la citada tradición socio-cultural pudiera incrementar la frecuencia e intensidad del fenómeno.

Teniendo en cuenta la solidez de las tesis que ponen el énfasis en problemas socio-económicos previos a la conquista romana hemos de destacar, sin embargo, que los autores antiguos transmiten las noticias de bandolerismo en el ámbito lusitano y betúrico en épocas posteriores a la irrupción de Roma en el territorio, lo que indicaría que la política romana en la zona tuvo una responsabilidad capital en la agudización de esas contradicciones sociales ${ }^{87}$.

En otras zonas de Hispania, la conquista romana no tuvo las mismas consecuencias. En este sentido, las diferencias estarían en la estructura socio-económica, por una parte, de las comunidades lusitano-betúricas y, por otra, de las celtibéricas, pero también en el hecho de que Roma adoptó métodos diferentes

da, Museo Nacional de Arte Romano, 1993, págs. 24-25 (Cuadernos Emeritenses, 7); P. CIPRÉs, Guerra...,págs. 150 y 156 y ss.

${ }^{83}$ A. Monteneqro, "La conquista...", pág. 61; M. Salinas, "Problemática...", págs. 28-29; P. Ciprés, Guerra..., págs. 153-154; E. Pitıllas, “Una aproximación...”, pág. 138.

${ }^{84}$ P. CIPRÉs, Guerra..., pág. 169.

${ }^{85}$ Martín Almagro-Gorbea, "El origen de los celtas...”, págs. 12-16; Martín Almagro-Gorbea, "Urbanismo y sociedad en la Hispania húmeda", en M.A. de Blas y A. Villa (Eds.), Los poblados fortificados del noroeste de la Península Ibérica: formación y desarrollo de la cultura castreña. Coloquios de Arqueología en la cuenta del Navia, Navia, Ayuntamiento de Navia, 2002, págs. 65-69, con bibliografía; P. Ciprés, Guerra..., pág. 148; Mauricio Pastor Muñoz, "La figura de Viriato y su importancia en la sociedad lusitana", en J.G. Gorges y T. Nogales (coord.), Sociedad y cultura en la Lusitania romana. IV Mesa Redonda Internacional, Mérida, Editora Regional de Extremadura, 2000, págs. 46-47. En cuanto al bandidaje formado por grupos de edad, uid. Diod., V, $34,4$.

${ }^{86}$ Ciprés hace referencia a otros pueblos a los que los autores grecolatinos asocian el bandidaje, como los Salasos y los Yápodas (P. CiPRÉs, Guerra..., pág. 139).

${ }^{87}$ Vid. supra. 
en ambos territorios. En Celtiberia, con un urbanismo más desarrollado, el sometimiento de las ciudades y la deditio fue un mecanismo habitual de poner fin a las hostilidades mientras que, en el suroeste la política romana, aun llevando a cabo pactos puntuales, adquirió un tono menos integrador ${ }^{88}$. En este sentido, Estrabón afirmaba que los romanos habían convertido en aldeas la mayor parte de sus ciudades ${ }^{89}$. La consecuencia es que, en torno al 141-140 a.C. ya son frecuentes las referencias a grupos sin tierras encabezados por líderes que se dedican al pillaje. Las campañas militares romanas de estos años habrían acrecentado esta situación, precisamente, en el área betúrica.

En definitiva, las consecuencias del incremento de las hostilidades en la zona en los años 141-140 a.C. fueron la conquista de ciudades, su saqueo y, por tanto, el abandono de las mismas por una parte de sus habitantes. Esto agudizó el surgimiento de grandes grupos de población dedicados a la guerra, las razzias en busca de botín y el pillaje, que eran dirigidos por líderes carismáticos, como Curio, Apuleyo o Cónnoba. El sucesor de Serviliano, Servilio Cepión, culminó su conquista de la región sur de Lusitania haciendo una razzia hacia el territorio de los vetones y los galaicos, lo que es difícil de comprender si no es en el contexto de persecuciones a estos grupos de guerreros ${ }^{90}$. También Junio Bruto tuvo la misión de acabar con los saqueos que se producían en toda Lusitania por salteadores que querían emular las actuaciones de Viriato ${ }^{91}$.

Estos grupos encajan con la descripción que daba Estrabón a los emigrantes célticos y túrdulos que se habían desplazado hacia el Noroeste. Los veía como una expedición militar dirigida por cabecillas militares ${ }^{92}$. Por otra parte, el cruce del río Limia, que había supuesto la dispersión de estos emigrantes en varios grupos, había motivado, según Estrabón, su denominación como Lethe o "río del Olvido" $" 93$.

\footnotetext{
${ }^{88}$ Ciprés contrapone ambos métodos de conquista, en Celtiberia con la sumisión de los núcleos habitados y, en Lusitania, mediante el desbaratamiento de la fuerza militar, seguido de acciones de castigo (P. CIPRÉs, Guerra..., págs. 135-136).

${ }^{89}$ Str., Geog., III, $3,5$.

${ }^{90}$ App., Iber., 70; P. CIPRÉs, Guerra..., pág. 72.

91 App., Iber., 71; P. CIPRÉs, Guerra..., págs. 70-72.

${ }^{92}$ Según P. Ciprés, Guerra ..., pág. 138, la identificación entre soldados y bandidos por los autores grecorromanos es clara en Apiano (Iber., 68), Diodoro (XXXIII, 1, 1-5) y en Estrabón (Geog., III, $4,15)$.

${ }^{93}$ Str., Geog., III, 3, 5; Plin., nat., IV, 115. Vid. Marco V. García Quintela, "El río del olvido (variaciones en torno a un episodio de la conquista de Hispania)", en J.C. Bermejo, Mitología y mitos de la Hispania prerromana 2, Madrid, Akal, 1986, pág. 77. Para Witczak, las fuentes antiguas

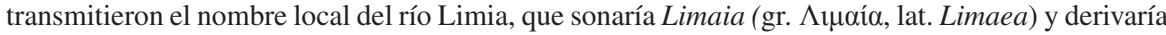
de una raíz indoeuropea *lei-m- «inundar, desbordar, ahogar» que generó diversos hidrónimos en Europa y que fue relacionada a nivel popular con un apelativo lusitano, quizá también indoeuropeo,
} 
A finales de la primavera del 137 a.C., cuando las tropas de Décimo Junio Bruto intenten cruzar el río Limia en su expedición contra "los celtas, los lusitanos y todos los pueblos de Gallaecia", la leyenda del "río del Olvido" impactó y sembró el temor entre los soldados romanos ${ }^{94}$, hasta el punto de que Bruto tuvo que cruzar el río en primer lugar con el estandarte y reclamar al ejército, desde la otra orilla, que lo cruzara ${ }^{95}$. Es muy probable, como afirmaba García Quintela, que el mito no tuviera su verdadero origen en la pérdida de memoria de célticos y túrdulos cuando cruzaron el río Limia y, en cambio, que fuera un mito preexistente en ese territorio ${ }^{96}$. Sin embargo, para la fuente de Estrabón, la migración celto-túrdula habría dado origen a la leyenda, lo que indicaría que el desplazamiento de población debió ser anterior a la expedición de Bruto, pero lo suficientemente cercana en el tiempo como para que estuviera todavía muy presente para los soldados romanos ${ }^{97}$.

La coherencia que, en nuestra opinión, ofrece la cronología del 141-140 a.C. para el desplazamiento de los célticos y túrdulos hacia el noroeste de la Península Ibérica, a partir de los acontecimientos político-militares que narran las fuentes literarias debe ser, en cualquier caso, cotejada con los datos que ofrece el registro arqueológico, tanto en la región betúrica, como en el noroeste peninsular.

\section{LAS HUELLAS DE VACÍOS POBLACIONALES EN LA BETURIA}

Berrocal apuntaba la fecha, que calificaba de arbitraria, del 175 a.C. para referirse a una nueva fase en el poblamiento del territorio betúrico, la que llamaba

que expresaba la acción de olvidar (Krzysztof Tomasz Witczak, "El río del Olvido", Veleia 20 (2003), págs. 357-359).

${ }^{94}$ Flor., 1, 33, 12: Decimus Brutus aliquanto latius Celticos Lusitanosque et omnis Callaeciae populos formidatumque militibus flumen Obliuionis, peragratoque uictor Oceani litore non prius signa conuertit quam cadentem in maria solem obrutumque aquis ignem non sine quodam sacrilegii metu et horrore deprendit.

${ }^{95}$ Liv., Per., 55: Decimus Iunius Lusitaniam expugnationibus urbium usque ad Oceanum perdomuit, et cum flumen Oblivionem transire nollent, raptum signifero signum ipse transtulit et sic, ut transgrederentur persuasit. Sobre este episodio, uid. J. Alarcão, Portugal..., pág. 37; C. ToRres Rodríguez, "La conquista romana...", pág. 16; C. Torres Rodríguez, La Galicia..., págs. 30-31; A. Tranoy, La Galice ..., pág. 127; M.V. García Quintela, "El río del Olvido...", págs. 77 y ss.; N. Santos Yanguas, El ejército..., pág. 32; K.T. WitczaK, "El río...", pág. 356.

${ }^{96}$ M.V. García Quintela, "El río del Olvido...”, págs. 78 y ss.; Marco V. García Quintela, "Las puertas del infierno y el río del olvido (un tema mítico céltico en la etnografía ibérica de Estrabón)", Gallaecia, 16 (1997), págs. 145-157.

${ }^{97}$ Teniendo en cuenta el texto de Estrabón, no cabe pensar que la expedición de célticos y túrdulos se hubiera llevado a cabo por éstos como soldados auxiliares de los romanos. En este sentido, uid. M.V. García Quintela, "El río del Olvido...”, pág. 81, n. 27. No obstante, este autor interpreta el texto de Estrabón como una transformación del de Livio (ibid., pág. 82 y M.V. García Quintela, "Las puertas...", págs. 146 y 152) que convertía a los soldados de Bruto en indígenas hispanos. 
fase $\mathrm{III}^{98}$. El autor establecía esta fecha por ser intermedia entre la del 185 a.C., que él llamaba "la primera ofensiva de las legiones romanas sobre el Suroeste" y la del 152 a.C., con la toma de Nertóbriga ${ }^{99}$. Ya vimos arriba que la campaña que Marcelo llevó a cabo el 152 en la Ulterior en relación con la supuesta Nergobriga que Berrocal relaciona con la Nertóbriga pliniana, puede estar basada en una sucesión de errores derivados de Polibio y Apiano ${ }^{100}$. En cuanto a la Beturia túrdula, también se considera sólida la fecha de mediados del s. II a.C. como momento que marca la disolución de los túrdulos como etnia prerromana, en relación con la conquista y reorganización del territorio por parte de Roma ${ }^{101}$.

Como ya vimos, uno de los yacimientos que puede ser relacionado con más solidez con el contexto de la expansión romana en la Beturia es el castro de Castrejón de Capote (Higuera la Real, Badajoz). El registro ofrece materiales, como cerámicas áticas de barniz negro, que permiten datar su uso entre los inicios del s. IV y la primera mitad del II a.C. (nivel III). En este nivel se halló el llamado "santuario A", en el que se descubrió una mesa de piedra sobre la que habían restos de una parrilla de hierro junto a un asador, cuchillos curvos y otros materiales relacionados con el altar, lo que indicaría su función como lugar ritual donde se realizaron ofrendas cárnicas, con sacrificios de numerosos cuadrúpedos, y distintos tipos de libaciones que se habrían realizado desde el s. IV hasta mediados del s. II a.C. En este momento, los rituales cesaron por completo, puesto que los niveles aparecen cerrados en algunos puntos por capas de ceniza y carbones, que serían indicios de incendios y destrucción repentina ${ }^{102}$.

Los materiales muestran una falta de importaciones itálicas o de monedas y de materiales metálicos, muy frecuentes a lo largo del s. II a. C. ${ }^{103}$. En un nivel

\footnotetext{
${ }^{98}$ L. Berrocal-Rangel, Los pueblos célticos..., pág. 278; L. Berrocal-Rangel, "La Beturia: definición y caracterización de un territorio prerromano”, en A. Velázquez y J.J. Enríquez (eds.), Celtas y túrdulos: la Beturia, Mérida, Museo Nacional de Arte Romano y Asociación de Amigos del Museo, 1995, pág. 173 (Cuadernos Emeritenses, 9).

99 L. Berrocal-Rangel, Los pueblos célticos..., pág. 278.

${ }^{100}$ Vid. supra.

${ }^{101}$ A. Rodríguez Díaz, "Territorios y etnias...”, pág. 214.

${ }^{102}$ L. Berrocal-RAngel, "El asentamiento...", págs. 253-257; Luis Berrocal-Rangel, "Banquetes y rituales colectivos en el suroeste peninsular", CuPAUAM 30 (2004), pág. 108; Luis BERROCAL-RANGEL, "El poblado fortificado de El Castrejón de Capote y su paisaje: la fortificación de lo sagrado", en Paisajes fortificados de la Edad del Hierro. Las murallas protohistóricas de la Meseta y la vertiente atlántica en su contexto europeo, en L. Berrocal-Rangel y Pierre Moret (eds), Madrid, Real Academia de la Historia, Casa de Velázquez, 2007, pág. 256; L. BerrocAL-RANGEL, "Episodios de guerra en los poblados indígenas de Hispania céltica: criterios para la identificación arqueológica de la conquista romana”, Salduie, 8 (2008), pág. 189; A. RodRíGuez DíAz, Extremadura tartésica: arqueología de un proceso periférico, Barcelona, Bellaterra, 2001, págs. 280-281. ${ }^{103}$ Luis BerRocAL-RANGEL, El altar prerromano de Castrejón de Capote. Ensayo etno-arqueológico de un ritual céltico en el suroeste peninsular, Madrid, Universidad Autónoma de Madrid, 1994,
} 
posterior, la habitación del santuario es amortizada, cubriendo el depósito ritual de modo intencionado, sin que aparezcan nuevas construcciones en el mismo ${ }^{104}$. A partir de aquí, la segunda mitad del s. II ya presenta múltiples cambios arquitectónicos, en la cerámica, muestra la aparición de la escritura y nuevos materiales de importación meridional e itálica que reflejan una apertura socio-económica al Mediterráneo hasta que el santuario se abandonó a finales del s. II a.C ${ }^{105}$.

La fase I de Los Castillejos-2 de Fuente de Cantos, fechada entre los siglos IV-III a.C., se relaciona con cierta claridad con Castrejón de Capote, ya que se interrumpe también con una destrucción violenta que se suele relacionar con la primera irrupción romana en el territorio. El lugar se reconstruye en poco tiempo con sistemas constructivos semejantes que definirían su fase II en el s. II a.C., ya con una mayor presencia de materiales cerámicos itálicos, como cerámicas de barniz negro y ánforas Dressel IA ${ }^{106}$. También la Ermita de Belén (Zafra, Badajoz), muestra dos fases de ocupación prerromana (fases I y II) seguidas de una fase III ya caracterizada por una ocupación romana hasta los primeros años de la Era $^{107}$.

La Alcazaba de Badajoz en su fase IV, se inicia a partir del s. IV a.C. y muestra una continuidad en el poblamiento hasta el s. II a.C., concluyendo con una violenta destrucción datable en torno al 150 a.C., sobre la que aparece ya la ocupación romana del lugar, con desaparición de los elementos culturales más relevantes del horizonte indígena y progresiva aparición de las producciones ro$\operatorname{manas}^{108}$. De modo parecido, el castro de la Mesilla (Alange, Badajoz), presenta la misma cronología que los citados hasta que en el s. II a.C. prácticamente se extingue $^{109}$.

El Castillo de Santa Olalla del Cala, asentamiento que arrancando desde época protohistórica, en torno al s. VII a.C., se prolonga hasta época bajomedieval, muestra en los primeros niveles cerámicas a torno, de almacenamiento y cocina del tipo B del túmulo de Setefilla y algún elemento metálico de influencia orientalizante. A esta fase le sigue otra caracterizada por un predominio de las cerámi-

\footnotetext{
págs. 261-262.

${ }^{104}$ L. Berrocal-RANGel, "Banquetes y rituales...", pág. 108.

${ }^{105}$ L. Berrocal-Rangel, "El asentamiento...”, pág. 259; L. Berrocal-RAngel, "Episodios...”, págs. 187-188.

${ }^{106}$ J. M. Fernández Corrales, F. J. Heras y Enrique Cerrillo; "Los Castillejos de Fuente de Cantos: un conjunto fortificado de época protohistórica en el sur de Badajoz" [en línea] disponible en <www.dip-badajoz.es/cultura/ceex/reex_digital/reex../RV000001.pdf> [consulta 10/05/2013], Badajoz, 1988, pág. 920; A. Rodríguez DíAz, Extremadura tartésica..., pág. 276.

${ }^{107}$ A. Rodríguez Díaz, Extremadura tartésica..., pág. 274.

${ }^{108}$ A. Rodríguez DíAz, Extremadura tartésica..., págs. 276-277.

${ }^{109}$ Ignacio Pavón, "El castro de "La Mesilla" (Alange, Badajoz): apuntes para la definición de la segunda Edad del Hierro en el valle del Matachel”, CuPAUAM, 23 (1996), págs. 155-157.
} 
cas a mano sobre los tipos a torno, con colores negros y grises, de mala factura y desgrasante grueso. Encuentra paralelos con el resto del entorno céltico, como el poblado de la Martela. Tras este período, el cual está sellado por un nivel de incendios, se produce un hiatus y el área no se volverá a ocupar hasta el periodo almohade $^{110}$. Este vacío ocupacional podría relacionarse, según Bermejo, con la destrucción del enclave en torno al s. II a.C. por parte de Roma, en sus campañas contra las poblaciones y núcleos célticos ${ }^{111}$.

El pico de la Muela de Aroche (Huelva) es abandonado durante la segunda mitad del s. II a.C., según Pérez Macías, por la irrupción militar romana y quizá su población recaló en los nuevos enclaves promocionados por Roma ${ }^{112}$, panorama que ofrece similitudes con el de Sierra de la Martela (Segura de León, Badajoz) en su nivel II (s. IV-II a.C. $)^{113}$ y con el de la Tabla de las Cañas ${ }^{114}$. También Las Dehesillas o Las Mesillas (Higuera de Llerena, Badajoz), era un castro indígena de unas 5 ha que aparece a comienzos de la Edad de Hierro y tiene su declive a mediados del s. II a.C., estando situado a $6 \mathrm{~km}$ del campamento romano del "Pedrosillo", que se databa, como vimos, también en ese mismo período ${ }^{115}$.

A partir de los datos expuestos, vemos que el impacto que translucen las fuentes literarias sobre el territorio betúrico en torno a los años 141-139 a.C. tiene un claro reflejo en los registros arqueológicos, con abandono de diversos lugares poblados que se pueden datar en ese período aunque, como es lógico, sin que podamos precisar el momento exacto en que se produjo.

\section{Huellas DE CAMBios POBLACIONALES EN EL NOROESTE}

No tenemos datos epigráficos o arqueológicos que establezcan vinculaciones directas e incontestables entre los célticos del noroeste o los túrdulos de la costa atlántica y los habitantes de la Beturia. Según González Ruibal, la antroponimia no corrobora los desplazamientos de población desde la Beturia céltica hacia el Noroeste ${ }^{116}$. Efectivamente, sería de esperar una relación antroponímica entre

\footnotetext{
${ }^{110}$ J. Bermejo MelÉndez, Un modelo de implantación..., págs. 168-169.

${ }^{111}$ J. Bermejo MelÉNDEZ, Un modelo de implantación..., págs. 168-169.

${ }^{112}$ Juan Aurelio Pérez Macías, "El Puerto de la Muela (Aroche, Huelva). Nuevo asentamiento prerromano en la margen izquierda del Guadiana", Norba, 11-12 (1991-1992), pág. 132.

${ }^{113}$ Luis Berrocal-Rangel, "Oppida y castros de la Beturia céltica", en M. Almagro-Gorbea y A.M. Martín Bravo (eds.), Castros y oppida en Extremadura, Madrid, Universidad Complutense, 1994, pág. 228 (Serie Complutum Extra, 4).

${ }^{114}$ Coronada Domínguez de la Concha y Juan García Blanco, "La Tabla de las Cañas (Capilla, Badajoz). Apuntes preliminares", I Jornadas de Prehistoria y Arqueología en Extremadura (19861990). Extremadura Arqueológica 2, Mérida-Cáceres, 1991, pág. 238.

${ }^{115}$ J.G. Gorges y F.G. Rodríguez Martín, "Les guerres...”, págs. 366 y ss.

${ }^{116}$ A. GonZález Ruibal, Galaicos..., pág. 465.
} 
ambas regiones visible todavía en la epigrafía de época alto-imperial pero, como afirmaba Albertos, sólo se pueden apuntar vinculaciones muy poco consistentes debido a que los datos epigráficos procedentes del occidente galaico son extremadamente escasos ${ }^{117}$. También podríamos esperar determinadas relaciones teonímicas, ya que entre los célticos del noroeste era adorado con cierta amplitud el dios indígena Cosus, pero aquí se da el caso contrario que con la antroponimia, ya que no tenemos registrados teónimos indígenas en la Beturia ${ }^{118}$. Además, nada impide que el teónimo Cosus fuera autóctono de Gallaecia, siendo venerado en el noroeste antes de que se produjera la migración que nos ocupa.

También son muchas las dificultades para encontrar relaciones directas entre el registro arqueológico de los castros de Gallaecia y del resto de la Península que nos permitan establecer un desplazamiento de población hacia el noroeste en un momento determinado ${ }^{119}$. Sin embargo, la taxativa afirmación de Estrabón, junto a las referencias de Plinio y Mela, los datos epigráficos alusivos a los célticos y túrdulos y las huellas de despoblamientos bruscos en yacimientos betúricos, inducen a buscar elementos de conexión que permitan establecer la certeza de dicha migración y su cronología ${ }^{120}$.

El propio Da Silva delimitaba, dentro de su secuenciación de la cultura castreña, una fase IIA con una cronología entre el 500 y el 200 a.C. con estímulos continentales post-hallstáticos donde, como citamos arriba, enmarcaba la migración de los túrdulos ${ }^{121}$, y una fase IIB que se iniciaría con la expedición de Junio Bruto y que ya comenzaba a mostrar importaciones itálicas, como las primeras cerámicas campanienses A. En este momento, se observan también más intensas relaciones entre indígenas y romanos, además de la introducción de la rueda de alfarero y el molino giratorio ${ }^{122}$, novedades arquitectónicas como el atrio o vestíbulo en las casas castreñas, lo que anunciaba nuevas influencias mediterráneas que serían visibles, al sur del Duero, en el castro de Romariz ${ }^{123}$.

\footnotetext{
${ }^{117}$ María Lourdes Albertos Firmat, "La onomástica personal indígena del noroeste peninsular (astures y galaicos)", en J.J. de Hoz (coord.), Actas del III Coloquio sobre Lenguas y Culturas Paleohispánicas (Lisboa, 5-8 Noviembre 1980), Salamanca, Universidad de Salamanca, 1985, pág. 305.

${ }^{118}$ Juan Carlos Olivares Pedreño, Los dioses de la Hispania céltica, Madrid, Real Academia de la Historia y Universidad de Alicante, 2002, págs. 157-160 (Bibliotheca Archaeologica Hispana, 15, Anejos de Lucentum, 7).

${ }^{119}$ A. GonZález Ruibal, Galaicos..., pág. 465; A.J. Lorrio Alvarado, "Los celtas...”, págs. 8283.

${ }^{120}$ Sobre la discusión del registro arqueológico y la presencia de célticos en Gallaecia, uid., A.J. Lorrio Alvarado, "Los celtas...”, págs. 69-78, en especial, 77.

${ }^{121}$ A.C.F. Da Silva, A cultura Castreja..., pág. 41.

${ }^{122}$ A.C.F. Da Silva, A cultura Castreja..., pág. 41; A.C.F. Da Silva, “A evolução...”, pág. 508.

${ }^{123}$ A.C.F. Da Silva, A cultura Castreja ..., págs. 42, 66-67 con gráfico 2 y 136; A.C.F. DA Silva, "A evolução...”, pág. 516; A.C.F. DA Silva, A cultura Castreja $2^{a}$ ed., págs. 51 y 81.
} 
Otros autores opinan también que, en los años posteriores a la citada expedición militar de Bruto, se iniciaría una fase marcada por la aparición de los oppida y por una nueva reestructuración del territorio ${ }^{124}$ que, aunque no directamente, pudo ser influida por la presencia de los romanos en el entorno ${ }^{125}$. Para González Ruibal, estos elementos que, a partir de mediados del s. II a.C., indican una mayor complejidad social, serían fruto de una evolución autóctona y de la citada presión de Roma, pero en ningún caso se puede hablar de Romanización ni la cercanía de los romanos sería la causa fundamental de este desarrollo, puesto que su período de máximo apogeo es a principios de s. I a.C. y comienza a decaer a finales de ese siglo y, además, estos oppida no siguen los patrones culturales de Roma ${ }^{126}$. En estos procesos habría que tener en cuenta, además, probables fenómenos de sinecismo y cambios de poblamiento durante la fase III que se prolongan ya desde finales del II a.C. en algunos $\operatorname{castros}^{127} \mathrm{y}$, finalmente, la cercanía de Roma pudo provocar alianzas entre comunidades castreñas y estimular indirectamente el surgimiento de los oppida ${ }^{128}$.

Se observan, por tanto, cambios importantes en el poblamiento de diversas áreas de Gallaecia a mediados del s. II a.C. que cambiarían plenamente el panorama arqueológico de la región y cuyas causas no parecen fáciles de establecer. Se adjudica a desarrollos autóctonos y, en parte, la influencia indirecta de Roma $^{129}$, pero los elementos que aparecen no son romanos y tampoco parece claro que sea un fenómeno evolutivo estrictamente autóctono.

En nuestra opinión, este crecimiento de población pudo estar estimulado por la llegada de comunidades desde el sur a causa de la política expansiva que

${ }^{124}$ A. González Ruibal, Galaicos..., 2006-2007, págs. 67-68; César Parcero Oubiña, Xurxo M. Ayán Vila, Pastor Fábrega Álvarez y Andrés Teira Brión; “Arqueología, paisaje y sociedad", en F. González García (Coord.), Los pueblos de la Galicia céltica, Madrid, Akal, 2007, págs. 219-224 y 239. Para Arias, ésta sería una subfase (II-I a.C.) del llamado Castrexo Pleno, que se caracteriza por la presencia de materiales de importación romana, evolución de la arquitectura (toda de piedra), en el arte y en la cultura material que se observa, sobre todo, en los castros de Borneiro, O Neixón Grande, Baroña, Castromao, Troña, Sta. Trega y A Lanzada (Felipe Arias ViLAs, "Las fases de la cultura castreña en Galicia: un debate abierto", en M.A. de Blas y A. Villa (Eds.), Los poblados fortificados del noroeste de la Península Ibérica: formación y desarrollo de la cultura castreña. Coloquios de Arqueología en la cuenta del Navia, Navia, Ayuntamiento de Navia, 2002, pág. 134).

${ }^{125}$ A. González Ruibal, Galaicos..., pág. 328; César Parcero Oubiña et al., "Arqueología...", págs. 223-224.

${ }^{126}$ A. González Ruibal, Galaicos..., págs. 335 y 336-337; C. Parcero Oubiña et al., "Arqueología...", págs. 224 y 240.

${ }^{127}$ A. González Ruibal, Galaicos..., págs. 338 y 345; C. Parcero Oubiña et al., "Arqueología...", pág. 231; A.C.F. Da Silva, A cultura castreja $2^{\mathrm{a}}$ ed..., págs. 81-82.

${ }^{128}$ A. GonZález Ruibal, Galaicos..., pág. 349.

${ }^{129}$ C. Parcero Oubiña et al., "Arqueología...", pág. 240; A.C.F. Da Silva, A cultura castreja, $2^{\text {a }}$ ed., pág. 189-190. 
Roma estaba llevando a cabo. Estos desplazamientos, entre los que podrían estar el de los célticos y túrdulos, habrían generado cambios en el poblamiento a partir de la segunda mitad del s. II a.C. A esta hipótesis se puede objetar que el ámbito donde más agudo fue el surgimiento de oppida como lugares centrales, fue el situado entre el Duero y el Miño donde, precisamente, no conocemos comunidades que se llamen a sí mismas célticas ni tampoco hay menciones de célticos por parte de los autores clásicos.

Sin embargo, la penetración de célticos y túrdulos en territorios del noroeste pudo tener distinto impacto según la región, siendo en alguna de ellas tan contundente que consiguió marcar las suficientes diferencias como para identificarse con respecto a las comunidades autóctonas, dejando huellas en la toponimia y, en consecuencia, motivando que los autores grecolatinos pudieran precisar cuáles eran sus territorios. Este sería el caso del sur del Duero, donde se ubicaban los túrdulos y también el del extremo noroeste peninsular, donde se situaban los grupos célticos, según las fuentes literarias y epigráficas. En cambio, en el área situada entre el Duero y las Rías Bajas de Galicia, donde no tenemos testimoniada la llegada de estas comunidades en los textos, tampoco podemos descartarla plenamente porque su impronta pudo ser menor, en función del grado de desarrollo y densidad poblacional de las comunidades autóctonas de esa región. Por otra parte, si la migración celto-túrdula se produjo en torno al 141 a.C., habría que tener en cuenta que cualquier cambio en el registro arqueológico que se produjera en estos momentos en las regiones situadas al sur del Miño se confundiría fácilmente con el impacto de la expedición militar de Junio Bruto, que fue sólo 3 años después, incrementando las dificultades para su identificación.

El modelo explicativo que planteamos está de acuerdo, por una parte, con la cronología tardía de los testimonios escritos, epigráficos o literarios, de poblaciones llamadas explícitamente túrdulas y célticas en el noroeste y, por otra, con la relativa continuidad en el poblamiento y en el registro arqueológico que se detecta desde el s. IV hasta mediados del s. II a.C. en muchas áreas de la cultura castreña.

\section{BIBLIOGRAFÍA}

Alarcão, Jorge, Portugal romano, Lisboa, Ed. Verbo, 1974.

Alarcão, Jorge, "Etnogeografía da Fachada Atlântica Ocidental da Península Ibérica", $P a$ leoetnología de la Península Ibérica: actas de la Reunión celebrada en la Facultad de Geografía e Historia de la Universidad Complutense, Madrid, 13-15 diciembre de 1989 Complutum, 2/3 (1992), págs. 339-346.

Albertos Firmat, María Lourdes, "La onomástica personal indígena del noroeste peninsular (astures y galaicos)", en J.J. de Hoz (coord.), Actas del III Coloquio sobre Lenguas y 
Culturas Paleohispánicas (Lisboa, 5-8 Noviembre 1980), Salamanca, Universidad de Salamanca, 1985, pág. 255-310.

Almagro-Gorbea, Martín, "El origen de los celtas en la Península Ibérica. Protoceltas y celtas", Polis. Revista de ideas y formas políticas de la Antigüedad Clásica, 4 (1992), págs. 5-31.

Almagro-Gorbea, Martín, "Urbanismo y sociedad en la Hispania húmeda”, en M.A. de Blas y A. Villa (Eds.), Los poblados fortificados del noroeste de la Península Ibérica: formación y desarrollo de la cultura castreña. Coloquios de Arqueología en la cuenta del Navia, Navia, Ayuntamiento de Navia, 2002, págs. 47-80.

Almagro-Gorbea, Martín y Mariano Torres Ortiz, "La colonización de la costa atlántica de Portugal: ¿fenicios o tartesios?”, Palaeohispanica, 9 (2009), págs. 113-142 (Acta Palaeohispanica $\mathrm{X}$ ).

Arias Vilas, Felipe, "Las fases de la cultura castreña en Galicia: un debate abierto", en M.A. de Blas y A. Villa (Eds.), Los poblados fortificados del noroeste de la Península Ibérica: formación y desarrollo de la cultura castreña. Coloquios de Arqueología en la cuenta del Navia, Navia, Ayuntamiento de Navia, 2002, pág. 127-138.

Astin, Alan E., Scipio Aemilianus, Oxford, Clarendon Press, 1967.

Beltrán Lloris, Francisco, "Plin. NH II 13-14 ¿Beturia Céltica o Convento Hispalense? A propósito de la estructura de la descripción pliniana de la Bética", en III Congreso Peninsular de Historia Antigua (Preactas II), Vitoria, Biblioteca Digital Hiberus, Universidad de Zaragoza, 1994, págs. 413-426.

Bermejo Meléndez, Javier, Un modelo de implantación territorial y municipal en la Baeturia Celtica: Arucci/Turobriga, civitas et territorium, Tesis Doctoral leída el 19 de noviembre de 2010, Huelva, Universidad de Huelva, 2011.

Berrocal-Rangel, Luis, "El asentamiento «céltico» del Castrejón de Capote (Higuera la Real, Badajoz)", CuPAUAM, 16 (1989), págs. 245-295.

Berrocal-Rangel, Luis, Los pueblos célticos del suroeste de la Península Ibérica, Madrid, Universidad Complutense, 1992 (Serie Complutum Extra, 2).

Berrocal-Rangel, Luis, El altar prerromano de Castrejón de Capote. Ensayo etno-arqueológico de un ritual céltico en el suroeste peninsular, Madrid, Universidad Autónoma de Madrid, 1994.

Berrocal-Rangel, Luis, "Oppida y castros de la Beturia céltica", en M. Almagro-Gorbea y A.M. Martín Bravo (eds.), Castros y oppida en Extremadura, Madrid, Universidad Complutense, 1994, págs. 189-241 (Serie Complutum Extra, 4).

Berrocal-Rangel, Luis, "La Beturia: definición y caracterización de un territorio prerromano", en A. Velázquez y J. J. Enríquez (eds.), Celtas y túrdulos: la Beturia, Mérida, 1995, págs. 151-204.

Berrocal-Rangel, Luis, La Baeturia. Un territorio prerromano en la Baja Extremadura, Badajoz, Diputación de Badajoz, 1998.

Berrocal-Rangel, Luis, "Banquetes y rituales colectivos en el suroeste peninsular", CuPAUAM 30 (2004), pág. 105-119.

Berrocal-Rangel, Luis, "El poblado fortificado de El Castrejón de Capote y su paisaje: la fortificación de lo sagrado", en L. Berrocal-Rangel y Pierre Moret (eds.), Paisajes forti- 
ficados de la Edad del Hierro. Las murallas protohistóricas de la Meseta y la vertiente atlántica en su contexto europeo, Actas del coloquio celebrado en la Casa de Velázquez, (Octubre de 2006), Madrid, Real Academia de la Historia-Casa de Velázquez, 2007, pág. 255-280.

Berrocal-Rangel, Luis, "Episodios de guerra en los poblados indígenas de Hispania céltica: criterios para la identificación arqueológica de la conquista romana", Salduie, 8, (2008), págs. 181-191.

Broughton, Thomas R.S., The Magistrates of the Roman Republic, vol. 1, New York, American Philological Association, 1951.

Cadiou, François, Hibera in terra miles. Les armées romaines et la conquête de l'Hispanie sous la République (218-45 av. J.-C.), Madrid, Casa de Velázquez, 2008.

Calo Lourido, Francisco, A Cultura Castrexa, Vigo, A Nosa Terra, 1993.

Caro Baroja, Julio, "La realeza y los reyes en la España Antigua”, Estudios sobre la España Antigua. Cuadernos de la Fundación Pastor, 17 (1971), págs. 53-159.

Ciprés, Pilar, Guerra y sociedad en la Hispania indoeuropea, Vitoria, Universidad del País Vasco, 1993 (Anejos Veleia, serie minor).

Diego Santos, Francisco, Inscripciones romanas de la provincia de León, León, Institución Fray Bernardino de Sahagún, Diputación Provincial de León, 1986.

Domínguez de la Concha, Coronada y Juan García Blanco, "La Tabla de las Cañas (Capilla, Badajoz). Apuntes preliminares", I Jornadas de Prehistoria y Arqueología en Extremadura (1986-1990). Extremadura Arqueológica II, Mérida-Cáceres, 1991, pág. 235-246.

Fernández Corrales, J.M., F.J. Heras y Enrique Cerrillo; "Los Castillejos de Fuente de Cantos: un conjunto fortificado de época protohistórica en el sur de Badajoz" [en línea] disponible en <www.dip-badajoz.es/cultura/ceex/reex_digital/reex../RV000001.pdf > [consulta 10/05/2013], Badajoz, 1988.

García Alonso, Juan Luis, La Península Ibérica en la Geografía de Claudio Ptolomeo, Vitoria, Universidad del País Vasco, 2003 (Anejos Veleia Serie Minor).

García Moreno, Luís Agustín, "Ciudades béticas de estirpe púnica (un ensayo postmarxista)", Dialoghi di Archeologia, 10 (1992), págs. 119-127.

García Quintela, Marco V., "El río del olvido (variaciones en torno a un episodio de la conquista de Hispania)", en J.C. Bermejo (ed.), Mitología y mitos de la Hispania prerromana 2, Madrid, Akal, 1986, págs. 75-86.

García Quintela, Marco V., "Las puertas del infierno y el río del olvido (un tema mítico céltico en la etnografía ibérica de Estrabón)”, Gallaecia, 16 (1997), págs. 145-157.

García y Bellido, Antonio, "Pequeñas invasiones y transmigraciones internas", AEArq., 23 (1951) págs. 490-496.

García y Bellido, Mª Paz, "Sobre las dos supuestas ciudades de la Bética llamadas Arsa. Testimonios púnicos en la Beturia túrdula", Anas, 4-5 (1991-1992), págs. 81-92.

González García, Francisco Javier, "Los célticos de Gallaecia: apuntes sobre etnicidad y territorialidad en la Edad del Hierro del Noroeste de la Península Ibérica”, Complutum, 22 (2011), págs. 117-132. 
González Ruibal, Alfredo, Galaicos. Poder y comunidad en el Noroeste de la Península Ibérica (1200 a.C. - 50 d.C.), A Coruña, Museu Arqueolóxico e Histórico da Coruña, 20062007 (Brigantium, 19).

Gorges, Jean-Gerard y Francisco Germán Rodríguez Martín; “Un probable complejo militar romano de época republicana en la Beturia túrdula: notas preliminares sobre el campamento del "Pedrosillo" (Casas de reina, Badajoz)", en A. Morillo (Coord.), Arqueología Militar Romana en Hispania: producción y abastecimiento en el ámbito militar (II Congreso Internacional de Arqueología militar romana en Hispania, León, 2004), León, Universidad de León, Ayuntamiento de León, 2006, págs. 655-669.

Gorges, Jean-Gerard y Francisco Germán Rodríguez Martín, "Les guerres lusitaniennes entre mythe, histoire et réalité: réflexions autour du complexe militaire romain du «Pedrosillo» (Casas de reina, Badajoz, Espagne)", en J.G. Gorges, J. d' Encarnação, T. Nogales Basarrate y A. Carvalho (coords.), Lusitânia romana - entre o mito e a realidade. Actas da VI mesa-redonda internacional sobre a Lusitânia romana, Cascais, Camara Municipal de Cascais, 2009, págs. 349-384.

Gorges, Jean-Gerard, Angel Morillo Cerdán, Francisco Germán Rodríguez Martín y Esperanza Martín Hernández; "Le campement romano-républicain du « Pedrosillo » (Casas de Reina, Badajoz, Espagne) à l'épreuve des sondages: premiers résultats de la campagne 2006", Limes 20, (XX Congreso Internacional de Estudios sobre Frontera Romana (León, 2006), vol. III, Madrid, 2009, (Gladius, anejos III, 2009), págs. 267-280.

Guerra, Amílcar; Plínio-o-Velho e a Lusitânia, Lisboa, Ed. Colibrí, 1995.

Gundel, Hans G., "Viriato, Lusitano, caudillo en las luchas contra los romanos. 147-139 antes de Cristo", Caesaraugusta, 31-32 (1968), págs. 175-198.

Haley, Evan W., Foreigners in Roman Imperial Spain: Investigations of Geographical Mobility in the Spanish Provinces of the Roman Empire 30 B.C.-A.D. 284, New York, Diss. Columbia Univ., 1986.

Jordá Cerdá, Francisco "Notas sobre la cultura castreña del noroeste peninsular", Memorias de Historia Antigua, 6 (1984), págs. 7-14.

Knapp, Robert, Aspects of the roman experience in Iberia. 206-100 B.C., Valladolid, Universidad de Valladolid, 1977.

Lintott, Andrew, "The Roman Empire and its problems in the late second century", The Cambridge Ancient History, vol. IX, The last age of the Roman Republic, 146-43 B.C., Cambridge, Cambridge University Press, 1992, págs. 16-39.

Lorrio Alvarado, Alberto J., "Los celtas en el occidente de Iberia", en Gonzalo Ruiz Zapatero y Jesús Álvarez-Sanchís (eds.), Castros y verracos. Las gentes de la Edad del Hierro en el occidente de Iberia, Ávila, Institución Gran Duque de Alba, Diputación de Ávila, 2011, págs. 45-100.

Mañanes, Tomás, Epigrafía y numismática de Astorga romana y su entorno, Salamanca, Universidad de Salamanca, 1982.

Marco Simón, Francisco, "Acerca de las migraciones célticas a la Península Ibérica”, en F. Marco, F. Pina y J. Remesal (eds.), Vivir en tierra extraña: emigración e integración cultural en el mundo antiguo: actas de la reunión celebrada en Zaragoza los días 2 y 3 de junio de 2003, Barcelona, Universitat de Barcelona, 2004, págs. 77-93 (col. Instrumenta, 16).

Meana, Mª José y Piñero, Félix, Estrabón. Geografía, libros III-IV, Madrid, Gredos, 1992. 
Montenegro, Angel, "La conquista de Hispania por Roma (218-19 antes de Jesucristo)", en Historia de España R. Menéndez Pidal, t. II.1. La conquista y la explotación económica, Madrid, Espasa-Calpe, 1986, págs. 4-192.

Olivares Pedreño, Juan Carlos, Los dioses de la Hispania céltica, Madrid, Real Academia de la Historia-Universidad de Alicante, 2002 (Bibliotheca Archaeologica Hispana, 15; Anejos de Lucentum, 7).

Parcero Oubiña, César, Xurxo M. Ayán Vila, Pastor Fábrega Álvarez y Andrés Teira Brión; "Arqueología, paisaje y sociedad", en F. González García (coord.), Los pueblos de la Galicia céltica, Madrid, Akal, 2007, págs. 131-258.

Pastor Muñoz, Mauricio, "La figura de Viriato y su importancia en la sociedad lusitana", en J.G. Gorges y T. Nogales (coord.), Sociedad y cultura en la Lusitania romana. IV Mesa Redonda Internacional, Mérida, Editora Regional de Extremadura, 2000, págs. 35-52.

Pavón, Ignacio, "El castro de "La Mesilla" (Alange, Badajoz): apuntes para la definición de la segunda Edad del Hierro en el valle del Matachel", CuPAUAM, 23 (1996), págs. 124-163.

Pérez Macías, Juan Aurelio, "El Puerto de la Muela (Aroche, Huelva). Nuevo asentamiento prerromano en la margen izquierda del Guadiana", Norba, 11-12 (1991-1992), págs. 131142.

Pina Polo, Francisco, "Deportaciones como castigo e instrumento de colonización durante la República romana: el caso de Hispania”, en F. Marco Simón, F. Pina Polo y J. Remesal Rodríguez, J. (eds.), Vivir en tierra extraña. Emigración e integración cultural en el mundo antiguo. Actas de la reunión realizada en Zaragoza los días 2 y 3 de junio de 2003, Barcelona, Universitat de Barcelona, 2004, págs. 211-246.

Pitillas, Eduardo, "Una aproximación a las reacciones indígenas frente al expansionismo romano en Hispania (205 al 133 a.n.e.)”, Memorias de Historia Antigua, 17 (1996), págs. 133-155.

Prósper Pérez, Blanca María, Lenguas y religiones prerromanas en el Occidente de la Península Ibérica, Salamanca, Universidad de Salamanca, 2002.

Quesada, Fernando, "La guerra en las comunidades ibéricas (c. 237-c. 195 a. C.): un modelo interpretativo", en A. Morillo, F. Cadiou y D. Hourcade (eds.), Defensa y territorio en Hispania de los Escipiones a Augusto: (espacios urbanos y rurales, municipales y provinciales): coloquio celebrado en la Casa de Velázquez (19 y 20 de marzo de 2001), León, Universidad de León, Secretariado de Publicaciones y Medios Audiovisuales, Casa de Velázquez, 2003, págs. 101-158.

Rabanal Alonso, Manuel Abilio y Sonia María García Martínez, Epigrafía romana de la provincia de León. Revisión y actualización, León, Universidad de León, 2001.

Ramírez Sádaba, José Luis, "Integración onomástica y social de los indígenas de la Beturia Céltica”, Palaeohispanica, 9 (2009), págs. 215-226 (Acta Palaeohispanica X).

Richardson, John S., Hispaniae. Spain and the development of Roman imperialism, 218-82 $B C$., Cambridge, Cambridge University Press, 1986.

Rodríguez Colmenero, Antonio, Galicia meridional romana, Bilbao, Universidad de Deusto, 1977.

Rodríguez Colmenero, Antonio, "Sobre dos nuevas estelas monumentales de Lucus Augusti", en F. Villar y Fl Beltrán (eds.), Pueblos, lenguas y escrituras en la Hispania prerromana, Salamanca, Universidad de Salamanca e Institución "Fernando el Católico" de la Diputa- 
ción de Salamanca, 1999, págs. 616-617 (Actas del VII Coloquio sobre Lenguas y Culturas Paleohispánicas, Zaragoza, 12 a 15 de Marzo de 1997).

Rodríguez Díaz, Alonso, "Sobre la periferia turdetana y la configuración diversa de la Beturia prerromana. Célticos y túrdulos en el Guadiana medio", SPAL, 2 (1993), págs. 243-267.

Rodríguez Díaz, Alonso, "Territorios y etnias prerromanas en el Guadiana medio: aproximación arqueológica a la Beturia túrdula", en A. Velázquez y J.J. Enríquez (coords.): Celtas y túrdulos: la Beturia, Mérida, Museo Nacional de Arte Romano y Asociación de Amigos del Museo, 1995, págs. 205-254 (Cuadernos Emeritenses, 9).

Rodríguez Díaz, Alonso y J.J. Enríquez Navascués, Extremadura tartésica: arqueología de un proceso periférico, Barcelona, Ed. Bellaterra, 2001.

Roldán, José Manuel, La República Romana, Madrid, Cátedra, 2010.

Ruiz Rodríguez, Arturo, "El concepto de clientela en la sociedad de los príncipes", en C. Mata Parreño y G. Pérez Jordà (eds.), Ibers. Agricultors, artesans i comerciants. III Reunió sobre Economia en el Món Ibèric, Valencia, 2000, págs. 11-20 (Saguntum extra, 3).

Salinas de Frías, Manuel, "Las fuentes clásicas y el poblamiento prerromano del occidente peninsular", en G. Ruiz Zapatero y J. Álvarez-Sanchís (eds.), Castros y verracos. Las gentes de la Edad del Hierro en el occidente de Iberia, Ávila, Institución Gran Duque de Alba, Diputación de Ávila, 2011, págs. 129-158.

Santos Yanguas, Narciso, "La conquista romana del N.O. de la Península Ibérica", Latomus, 41/1 (1982), págs. 5-49.

Santos Yanguas, Narciso, El ejército y la romanización de Galicia, Oviedo, Universidad de Oviedo, 1988.

Sayas, Juan José, "El bandolerismo lusitano y la falta de tierras", Espacio, Tiempo y Forma (HA), 4 (1989), págs. 701-714.

Sayas, Juan José, “Algunas consideraciones sobre cuestiones relacionadas con la conquista y romanización de las tierras extremeñas", en El proceso histórico de la Lusitania oriental en época prerromana y romana, Mérida, Museo Nacional de Arte Romano, 1993, págs. 189-233 (Cuadernos Emeritenses, 7).

Schulten, Adolf, Fontes Hispaniae Antiquae III. Las guerras de 237-154 a. de J.C., Barcelona, Universidad de Barcelona, 1935.

Schulten, Adolf, Fontes Hispaniae Antiquae IV. Las guerras de 154-72 a. de J.C., Barcelona, Universidad de Barcelona, 1937.

Silva, Armando Coelho Ferreira da, "As tesserae hospitalis de Castro de Senhora de Saude ou Monte Murado (Pedroso V. N. Gaia). Contributo para o Estudio da institucões o povoamento da Hispania Antigua", Gaia, 1 (1983), págs. 9-26.

Silva, Armando Coelho Ferreira da, A cultura castreja no noroeste de Portugal, Paços de Ferreira, Museu Arqueológico da Citania de Sanfins, 1986.

Silva, Armando Coelho Ferreira da, "A evolução do hábitat castrejo e o proceso de protourbanização no noroeste de Portugal durante o I milénio a.C.", Revista da Facultade de Letras. Historia, 12 (1995), págs. 505-546.

Silva, Armando Coelho Ferreira da, A cultura castreja no noroeste de Portugal (2 $2^{\mathrm{a}}$ edición), Paços de Ferreira, Câmara Municipal de Paços de Ferreira, Museu Arqueológico da Citania de Sanfins y Centro de Arqueología Castreja e Estudos Célticos, 2007. 
Steel, Catherine, The end of the Roman Republic, 146 to 44 B.C. Conquest and crisis, Edimburgo, Edinburgh University Press, 2013.

Thouvenot, Raymond, Essai sur la province romaine de Bétique, París, de Boccard, 1973.

Torres Rodríguez, Casimiro, "La conquista romana de Galicia", en La romanización de Galicia. Cuadernos del Seminario de Estudios Cerámicos de Sargadelos 16, Sada-La Coruña, 1976.

Torres Rodríguez, Casimiro, La Galicia romana, A Coruña, Fundación Pedro Barrié de la Maza, 1982 (Colección Galicia Histórica).

Tranoy, Alain, La Galice romaine. Recherches sur le nord-ouest de la péninsule Ibérique dans l'Antiquité, París, de Boccard, 1981.

Untermann, Jurgen, "Célticos y túrdulos”, Palaeohispanica, 4 (2004), págs. 199-214.

Witczak, Krzysztof Tomasz, "El río del Olvido", Veleia, 20 (2003), págs. 355-359. 